\title{
Early Urbanism in Northern Mesopotamia
}

\author{
Augusta McMahon ${ }^{1}$
}

Published online: 31 August 2019

(C) The Author(s) 2019

\begin{abstract}
Cities generate challenges as well as confer advantages on their inhabitants. Recent excavations and surveys in northern Mesopotamia have revealed extensive settlements with diverse populations, institutions, extended hinterlands, and mass production by the early fourth millennium BC, comparable to well-known evidence for cities in their traditional homeland of southern Iraq. However, early northern Mesopotamian cities incorporated low-density zones and flexible uses of space not yet identified in southern Mesopotamia. Evidence for violent conflict in northern Mesopotamian cities also raises questions about urban sustainability; cities succeeded despite new sources of social stress.
\end{abstract}

Keywords Early cities · Urbanism · Urban sustainability $\cdot$ Mesopotamia

\section{Introduction}

Cities are extraordinarily successful and adaptable, present in almost every region around the globe. More than $50 \%$ of the world's population currently lives in cities, with projections increasing for the foreseeable future (Bettencourt and West 2010). Yet sociology and urban planning literature is rife with negatives of urban living: crowding, poverty, unemployment, crime, inadequate municipal services, and inefficient transportation. Cities are sources of creativity and innovation (Glaeser 2011; Hall 1998; Hietala and Clark 2013; Jacobs 1969; Landry 2000) but also sprawling resource drains (Dyball and Newell 2015). Successful settlements that persist for centuries and attract steady streams of immigrants may nevertheless have negative impacts on individuals, human groups, and other species.

Were ancient cities similarly contradictory? Did the world's earliest cities also experience the world's earliest urban problems? Since V. G. Childe (1950), archaeologists have described and deconstructed the city. But studies of ancient cities tend

Augusta McMahon

amm36@cam.ac.uk

1 Department of Archaeology, University of Cambridge, Downing Street, Cambridge CB2 3DZ, UK 
to focus on positive aspects: defense, economic efficiency, or inventions such as writing and mathematics. Cities are lauded as safety nets, employers, and collaborative communities.

However, chaotic modern megacities should test our assumptions of positive urban order in the past. In addition, the earliest cities were new social experiments, untested arrangements of unprecedented numbers of people; cities were vectors of disease, loci of isolating poverty (Algaze 2018), and deep wells of inequality. Early urban dwellers made compromises. High population density allows efficient information exchange, collaboration, and innovation (Glaeser 2011), but associated poor sanitation damages health at individual and group levels (Nichols 2006; Paine and Storey 2006; Storey 2006). Urban institutions provide economic safety nets but may impose disproportionate demands on labor and time. Crowding and growth of sociopolitical hierarchies can lead to violent conflict (McMahon et al. 2011). Through a series of themes, this article examines the negative and positive aspects of some of the world's earliest cities, in fourth millennium BC northern Mesopotamia.

My definition of ancient cities has four essential elements, physical and functional. The first is the classic combination of large size and diverse population, when compared to average site size in a region and the range of professions or identities represented therein. Based on modern definitions of cities, past cities should involve people living and working in close proximity, with fast, frequent interactions (Bettencourt and West 2010; Glaeser 2011; Sudjic 2016). Thus, the second essential element is the presence of urban infrastructure, or elements of the built environment, such as public space, access routes, and industrial zones, that reflect and amplify frequent social and economic interactions. This infrastructure may be derived from bottom-up tradition or top-down imposition. The third element is how cities act. They affect the surrounding region, through ideology, attraction of population, or resource drain; cities are capitals or focal points, whether this is of religious spheres, economic zones, or political units. The fourth element is the presence of authority or institutions, as materialized in highly visible public buildings.

\section{Mesopotamia, South and North}

Ancient Mesopotamia is roughly equivalent to the modern countries of Iraq, northeastern Syria, southeastern Turkey, and southwestern Iran (Fig. 1), an area that encompasses a wide range of topography and environmental zones but can be separated into southern and northern regions at a dividing line near modern Baghdad. With the exception of the Neo-Assyrian empire of northern Mesopotamia in the first millennium BC, the archaeology of southern Mesopotamia is the better known of the two regions. Many of the unique structures and most distinctive objects of ancient Mesopotamia_ziggurats (stepped temple towers), stelae, and archives of cuneiform texts-are strongly associated with the southern region. These aspects also postdate the region's earliest cities. Instead, formal public architecture, mass production of basic goods, and administrative artifacts are associated with the earliest cities in both southern and northern Mesopotamia. 


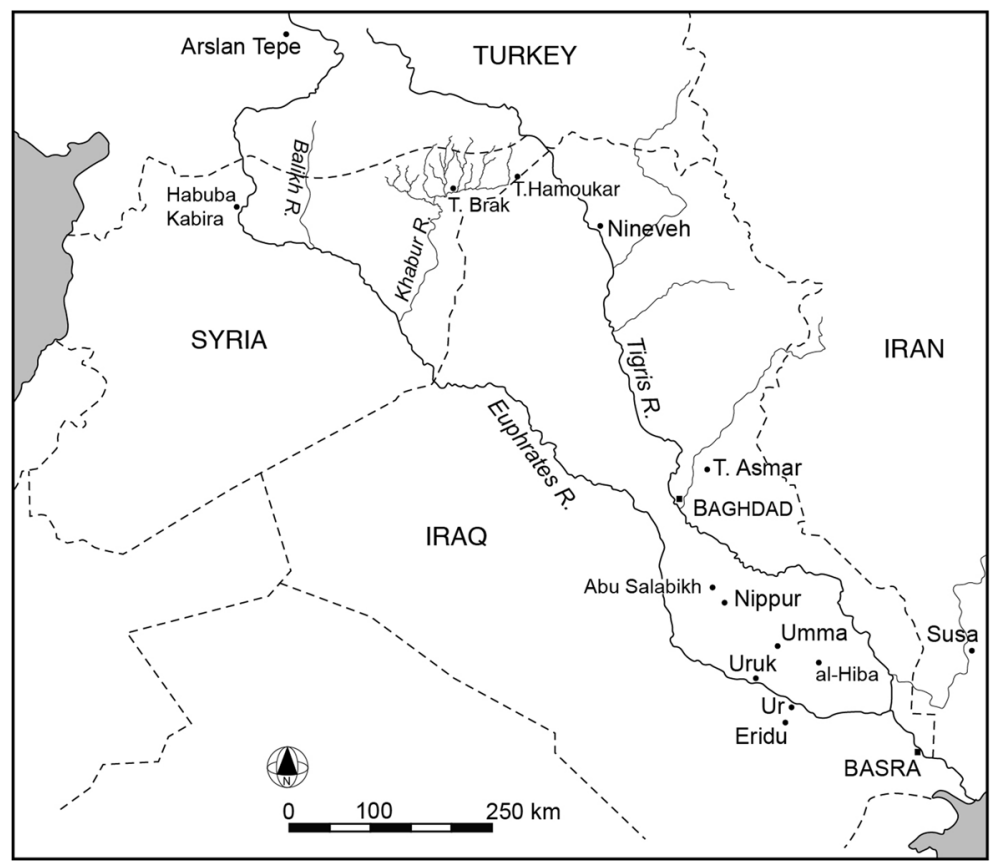

Fig. 1 Map of Mesopotamia with key sites indicated

Southern Mesopotamia - the alluvial plains of southern Iraq from Baghdad to the Gulf - is persistently identified as the location of the world's earliest cities (Adams 2012; Nissen 1988, 2001; Vallet 1997; van de Mieroop 1997; Yoffee 2015). Studies of the first Mesopotamian cities regularly focus on the site of Uruk, adjacent to the Euphrates River c. $250 \mathrm{~km}$ west-northwest of modern Basra (Algaze 2008; Crüsemann 2013; Liverani 2006; Modelski 2003; Nissen 2002). But beyond decades of research at Uruk and a brief excavation of the Uruk period mound of Abu Salabikh (Pollock 1990; Pollock et al. 1991), there has been little exploration of the fourth millennium BC in southern Iraq. Uruk's overlooked neighbors, such as Eridu in southern Iraq and Susa in southwestern Iran, had large religious institutions of the same or even earlier date. And other southern Mesopotamian settlements, such as Umma, may have been similarly urban in scale. But the size (c. 250 ha) and monumental structures of Uruk, and its pictographic writing and cylinder seals linked to leadership and administration, have cemented it firmly in general literature as the world's oldest city.

Meanwhile, urbanism in northern Mesopotamia has been largely relegated to a secondary process that occurred in the third millennium BC. The north in the fourth millennium BC has been described as a "complex chiefdom" or "proto-urban state" (Butterlin 2009). However, northern Mesopotamia-the rainfed farming region of northern Iraq, northeastern Syria, and southeastern Turkey-offers a further dynamic example of early cities and an alternative to widely accepted views about the location of the world's earliest urbanism. In the last three decades, evidence 
has accumulated for large, complex settlements in the north during the mid-to-late fourth millennium BC, contemporary with developments at Uruk and elsewhere in the south. These cities housed powerful institutions and absorbed immigrants and resources from a wide hinterland, and their diverse inhabitants engaged in mass production and long-distance trade. They were primary cities, not influenced by developments in the south, and their forms and trajectories of growth present intriguing contrasts to those of southern Mesopotamian cities.

In this article I present the current state of research into early northern Mesopotamian urbanism, isolating key themes and encompassing data from surveys and excavations. My focus is on the Upper Khabur of northeastern Syria and Jezira of northern Iraq (Fig. 2). Urbanism appeared there in the fourth millennium BC, while areas farther west on the Balikh River or northwest on the Syrian-Turkish Euphrates were connected but remained nonurban until the third millennium BC. Since this subject was last addressed in this journal (Ur 2010a), research flowed and then stalled due to the civil war in Syria. Conducting research in northern Iraq and along the borders between Turkey, Syria, and Iraq has been difficult for decades, and these important zones still remain artificially empty. New opportunities afforded by expansion of research in Kurdistan since 2011 have not yet had a great impact on our reconstruction of urbanism but hold potential for the future.

\section{The Discovery of Northern Mesopotamian Urbanism}

The identification of independent northern Mesopotamian urbanism derives in part from analysis of the "Uruk expansion" of the late fourth millennium BC, which involved movement of material culture and people outward from the southern Mesopotamian plains. Colonies, outposts, and influence, reflected by the presence of southern material culture and distinctive architecture, appeared in the Zagros

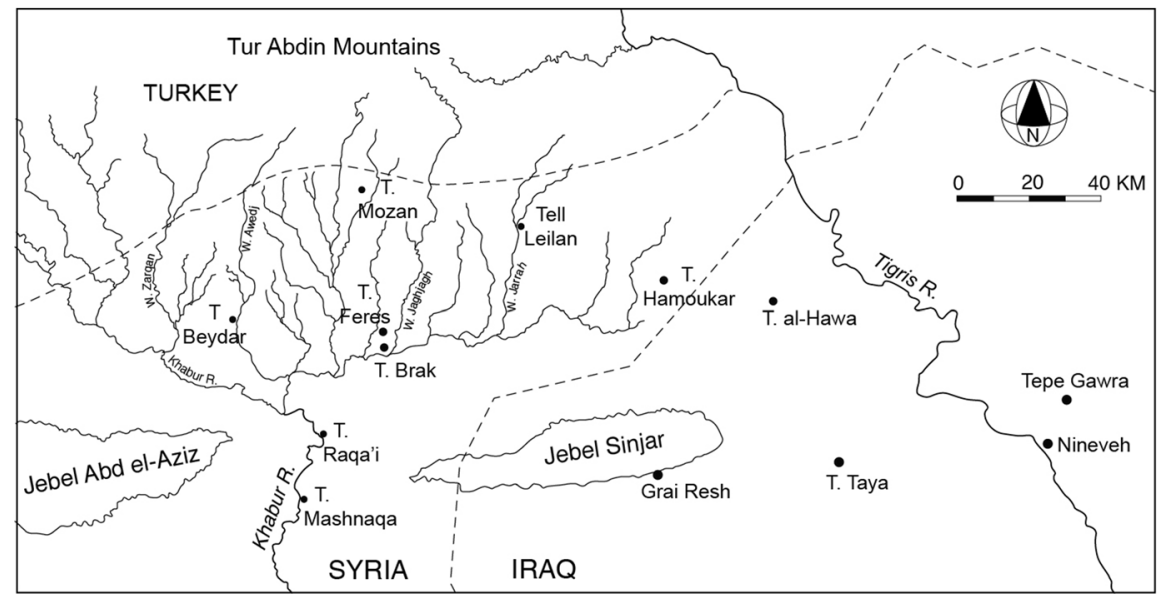

Fig. 2 Detailed map of northern Mesopotamia with sites mentioned in text 
Mountains to the east, across northern Iraq and northern Syria, and up the Euphrates River into Turkey.

The initial model for this southern expansion presented it as a colonizing surge from a complex and resource-poor core into an undeveloped but resource-rich periphery in search of timber, stone, and metals (Algaze 1993). Although true colony sites such as Habuba Kabira in Syria support this model, excavation of "outpost" sites such as Tell Brak, where local material culture persisted alongside foreign imports, necessitated a critical reassessment. The sophistication of Anatolian sites such as Arslantepe and northern Iraqi sites such as Tepe Gawra added to problems with the core-periphery idea. And when presouthern-contact evidence for massive architecture, division of labor, sophisticated metallurgy, and established elites was discovered at sites such as Hacınebi Tepe in southeastern Turkey, the asymmetrical core-periphery model came under sustained attack (Pearce 2000; Rothman 2004; Stein et al. 1996, 1997, 1998). Northern peoples would not have been easily dominated or colonized. The huge distance from southern cities-more than $1000 \mathrm{~km}$ - was an additional leveling factor. Reassessment led to rejection of southern Mesopotamian supremacy in favor of a balanced, negotiated, and mutually rewarding interaction among equals (Emberling 2003; Frangipane 2001, 2012; Gibson et al. 2002; Helwing 2000; Oates and Oates 1997; Rothman and Peasnall 1999; Stein 1999, 2002, 2012). Other explanations for the Uruk expansion include the flight of refugees (Johnson 1988-1989), search for farmland (Schwartz 1988a), and demand for sheep/goat pastureland (McCorriston 1997). Excavations in Transcaucasia are increasingly part of the discussion, as the evidence for large settlements and material culture connections to Mesopotamia is clarified (Lyonnet 2009; Marro 2010). This scholarly debate fueled a new vitality in exploration of northern Mesopotamia, leading directly to its identification as an independent locus of urban growth (Emberling 2002, 2003; J. Oates et al. 2007).

\section{Mesopotamian Chronology and Cultural Labels}

The chronological labels of northern Mesopotamia borrow from its western and southern neighbors: Late Chalcolithic from Anatolia and the Levant, and Uruk period from southern Mesopotamia. After decades of confusing, idiosyncratic labels (e.g., Northern Uruk, Gawran), most projects in northern Mesopotamia use the Late Chalcolithic (hereafter LC) phasing system established at a conference in Santa Fe in 1998 (Rothman 2001). The labels have remained stable since publication, although the absolute dating of the five phases (LC1-LC5) has been adjusted many times and is still in flux (Table 1). Urbanism is associated with LC2 and LC3.

Radiocarbon dates are often contradictory and remain approximations at best (Rupley and Wright 2001). Density of available dates varies across the region, and the absence of a full date sequence from any single site means that hinge dates, for phase transitions, remain flexible (Hole 2001). Even sites where long LC sequences have been exposed, such as Tell Brak, do not provide dates for every phase (Emberling and McDonald 2003). Pottery typologies of northwestern Syria, the Upper Euphrates, Upper Khabur, Iraqi Jezira, and Transcaucasia are thus key to 
Table 1 Chronological labels and approximate dates $\mathrm{BC}$

\begin{tabular}{lll}
\hline Dates BC & LC phase & $\begin{array}{l}\text { Southern Mesopo- } \\
\text { tamian equivalent }\end{array}$ \\
\hline $3400-3100$ BC & LC 5 & Late Uruk \\
$3600-3400$ BC & LC 4 & Late Middle Uruk \\
$3900-3600$ BC & LC 3 & Early Middle Uruk \\
$4200-3900$ BC & LC 2 & Early Uruk \\
$4400-4200$ BC & LC 1 & Late Ubaid \\
\hline
\end{tabular}

construction of relative chronology as well as regional interconnections (Helwing 2000; Marro 2010; Pearce 2000). After regionalization in Ubaid and LC1, larger eastern and western ceramic traditions are visible in LC2, which come closer in LC3. The LC4-5 pottery typologies are disrupted by the arrival of southern influence and, possibly, southern potters.

Our state of knowledge across the Late Chalcolithic is uneven, and ceramic typologies and phasing in pre-2001 publications have proved difficult to reconcile with the LC1-5 system (Lawrence and Wilkinson 2015). The preceding Late Ubaid period is well represented. But excavation of LC1 levels in northeastern Syria and northern Iraq is limited (Stein 2012). The situation is better for LC2 and thereafter but is still patchy, and ceramic typologies for LC2 and LC3 remain under construction. The most problematic moment is the late LC3 to LC4, when southern Uruk material culture spread across the region. The beginning of this expansion remains challenging to identify. There are occasional southern elements present in the north during the LC3, but their rarity makes them tricky to interpret: random import, intrepid trader, early adoption, or incorrect dating? The spread of southern material in the LC4 also was not comprehensive, and many sites in the north never embraced or perhaps actively rejected southern materials and peoples. Most importantly, local material culture traditions persisted from LC3 to LC4. Thus it remains difficult to date excavated assemblages that lack intrusive southern materials: are they precontact LC3 or entirely local LC4? This problem is amplified in surveys, where surface sherds are decontextualized.

\section{Environmental Setting of Northern Mesopotamian Cities}

Northern and southern Mesopotamia are defined by the Tigris and Euphrates Rivers, both of which depend on the rainfall and melting snows of the Taurus Mountains in Turkey and flow south into Syria and Iraq c. $400 \mathrm{~km}$ apart. They approach each other near Baghdad before diverging in southern Iraq and eventually flowing into marshes near the head of the Gulf (Fig. 1). The Euphrates has several tributaries within Syria: the Balikh and Khabur (which has its own tributaries); the Tigris is fed by additional rivers that flow southwest from the Zagros Mountains: the Upper and Lower Zab, Adhaim, and Diyala. The main resources of Mesopotamia were its fertile agricultural land and capacity for pastoral production. However, stands of 
timber, metal sources, and stone in the foothills and mountains were near northern cities and absent in the south.

The rivers that dissect the northern plains are currently dry for much of the year and have little associated permanent vegetation, but water availability was higher in the past, particularly during the period of urban growth. The Wadi Jaghjagh, for example, central to the Upper Khabur drainage, flowed year-round during the fourth millennium BC and supported beds of reeds and stands of poplar, willow, tamarisk, and ash trees (Charles et al. 2010; Deckers and Riehl 2007). The presence of oak woodland throughout most of the Upper Khabur has been suggested by analysis of archaeological charcoal and borehole profiles along the Wadi Jaghjagh, which additionally reflect a strong discharge rate in the mid-fourth millennium BC (Deckers $2011,2016)$. The north's topographic setting is relatively stable; wadis meander, but this is negligible when contrasted to the alluviation, flooding, and river shifts suffered in the south.

Annual rainfall also had an impact on past settlement and economies. Rain falls in November-April, meaning winter cultivation and spring harvests. The south's low rainfall - less than $200 \mathrm{~mm}$ rain per year-and its total reliance on irrigation can be contrasted to the north's capacity for rainfed agriculture. But the climate of the south in the era of urban growth was not as dire as supposed (Kennett and Kennett 2006; Pournelle 2003). Early in the fourth millennium BC, the rate of sea-level rise and infill of the Gulf was slowing, but rich pockets of marsh and coastal resources still intruded deep into what are now arid plains, supporting settlement growth. Rainfall decreased over the millennium, but aridity did not become severe until the early third millennium BC. The climate of the north was certainly more favorable for human occupation in the past, but it also has limits. The Upper Khabur and Iraqi Jezira lie above the 250 -mm annual rainfall isohyet which is the minimum for rainfed farming. However, the southern edge of this zone remains high risk, particularly for urban settlements with their demands for water and agricultural products.

Analyses of climatic data for northern Mesopotamia are inconclusive, with some suggesting a moister climate across the fourth millennium BC (Charles et al. 2010; Lawrence et al. 2017) and others supporting a gradual trend toward increased aridity (Roberts et al. 2011). The most dramatic climatic event, an episode of stress recorded in regional lake cores at c. 5200 BP/3200 BC (Charles et al. 2010; Riehl et al. 2014), postdates the region's earliest cities.

\section{Regional Scale Issues in Urbanization}

\section{City-Hinterland-Rural Relations}

"Hinterland" and "rural" are often used interchangeably, but here I use rural for settlements and hinterland for regions and landscapes. The relationship between cities and their hinterlands is a persistent theme in archaeological approaches to urbanism (Adams 1965, 1981; Adams and Nissen 1972; Finley 1977; Rich and WallaceHadrill 1991; M. L. Smith 2003; Zeder 2003). City dominance in its hinterland, as a market center, political core, ceremonial site, or military fortress, has also been 
highlighted in some urban definitions (Frangipane 2018; Janusek and Blom 2006; M. E. Smith 2008, 2016). Hinterlands are perhaps most important in economic terms. The lack of urban self-sufficiency in food production-with its inverse, reliance on an external oversupply - is the focus of many studies of city-hinterland relations and has also been used to define cities (Falconer 1994, p. 122). But resources beyond subsistence goods, such as timber, stones, and metals, also are extracted from hinterlands, and a city's rural settlements are its main suppliers of extra labor and consumers of its manufactured goods (M. L. Smith 2014). Thus, hinterlands are inherently flexible, especially during the early advent of cities. A city's hinterland may not be close to or contiguous with it; a richly resourced region may supply several different cities simultaneously.

The growth of cities created the linked concept of rural settlements (M. L. Smith 2003, 2014; Yoffee 1995). Cities effectively invert the focus of attention: urban settlements ruralize communities by shifting the supply-demand balance, creating a new focus of worship, extracting taxes or tribute, and altering villagers' mental maps. The contrast between rural and urban settlements and populations, in "activities, roles, practices, experiences, identities, and attitudes," is also part of city definition (Cowgill 2004, p. 526). However, the power imbalance traditionally assigned to city versus village cannot be upheld when one examines the rich material culture and economic diversity at many smaller sites and considers the complicated resource clustering that may afford some small settlements disproportionate economic power (Schwartz 2015; Schwartz and Falconer 1994). The simple model of rural agricultural communities supporting a "consumer city" (Finley 1977) is generally rejected (Hansen 2004), although the alternatives of "producer city" and "merchant city" have their adherents (Mattingly et al. 2001; Morris 2006). Our ability to assess the complex relationship among cities, rural settlements, and hinterlands in Mesopotamia is hampered by imbalanced evidence. Cities have been intensively examined, but small settlements are rarely excavated. The complexity of hinterland networks is only partially addressed by survey.

\section{Regional Surveys in Northern Mesopotamia}

The surveys of Adams (1965, 1981), Nissen (Adams and Nissen 1972), Wright (1981), and Gibson (1972) in southern Iraq were game-changing for Mesopotamian archaeology, in their scope and questions. The surveyors aimed to reconstruct past settlement patterns and their ebbs and flows in relation to political and climatic history. By the 1960s, northern Mesopotamia had seen decades of exploration and informal surveys undertaken to locate sites for excavation (e.g., Mallowan 1936). Pioneering aerial surveys of northern Mesopotamia between the World Wars (Hritz 2014; Poidebard 1927) were perhaps the first to take a holistic view of sites in their landscapes. But it was only after Adams' work in the south that surveys in northern Mesopotamia targeted long-term settlement patterns (Wilkinson 2000, 2003). Northern surveys comprised extensive regional projects in the 1970s-1990s (Lyonnet 1996, 2000; Meijer 1986; Wilkinson and Tucker 1995), intensive site- or wadi-focused research in the 1990s-2000s (Eidem and Warburton 1996; Ristvet 
2005; Stein and Wattenmaker 2003; Ur 2002a, b, 2010b; Ur and Wilkinson 2008; Wright et al. 2007), and "big data" projects in the 2010s that combine extensive and intensive approaches (Lawrence and Wilkinson 2015; Ur 2016; Wilkinson et al. 2014a). Most decades have also seen river valley salvage surveys ahead of flooding by hydroelectric projects. These shifts in focus correspond to developments in technology and resources, particularly the accessibility of high-resolution satellite imagery, such as the CORONA programme (Hritz 2014; Ur 2013), which has been successfully exploited to assist on-ground site targeting. The precision and intensity of survey coverage correspondingly improved over time; for instance, 90 sites were recorded in the initial 1984 survey of $15-\mathrm{km}$ radius around Tell Leilan, working from French 1:200,000 maps and local information (Ristvet 2005), versus 550 sites discovered in the 2004-2007 survey of a 15-km radius around Tell Brak, assisted by satellite imagery (J. Oates, personal communication 2010; Wright et al. 2007).

Satellite imagery (particularly CORONA and ASTER) and digital elevation model data allowed identification of over 14,000 sites in the Upper Khabur through moundedness (volume) and the multispectral, multitemporal signature of anthropogenic soils (Menze and Ur 2012). The vast scale and outstanding level of detail of this study support the importance of reliable water access and location within an exchange network as crucial for settlements' long-term success. While we await comparable ground-truth data from the south, satellite imagery has already revolutionized our understanding of the southern environmental context for urban growth, particularly the importance of the marshes (Pournelle 2007). Since 2011, surveys in Iraqi Kurdistan assisted by satellite imagery are revealing distinctive northeastern Mesopotamian settlement patterns (Altaweel et al. 2012; Gavagnin et al. 2016; Ur et al. 2013).

Extensive and intensive data have also been brought together in the large-scale Fragile Crescent Project (FCP) (Lawrence and Wilkinson 2015; Lawrence et al. 2017; Wilkinson et al. 2012, 2014a). The FCP merged old and new data from across northern Mesopotamia and northwestern Syria, recalibrating existing surveys and supplementing them with remote sensing techniques. Wilkinson and colleagues identified zones of optimal, suboptimal, and marginal potential for agriculture in the northern landscape. They then explored the potential for shifts between farming and herding and the added value of communication and trade routes, concluding that local variation and adaptability were key factors in northern urbanization. Particularly in poor lands with low rainfall, the "zone of uncertainty," a close relationship between herding and farming mitigated the risks of large population agglomeration.

The persistence of sites across periods of unequal length is a huge problem for survey, and the FCP developed a method using 100-year blocks to address this issue (Lawrence et al. 2017; Wilkinson et al. 2014a). This method also allows merging of surveys that used different chronological divisions, such as the North Jezira Survey, with its local Northern Uruk (LC2-4) and Later Uruk materials (LC4-5) (Wilkinson and Tucker 1995), and the Hamoukar Regional Survey, which separated LC1-2 from LC3-5 (Ur 2002a b, 2010b). The result of the FCP's reanalyses is a picture of dense and regularly spread rural settlement across the upper Khabur and northern Jezira in the fourth millennium BC. The cities were at the top of a two- or three-tier site-size hierarchy. 
Building on these data, Lawrence and Wilkinson's model of "hubs and upstarts" (2015) breaks down assumptions of inexorable settlement growth and accounts for collapses, downturns, and heterogeneity in regional trends. They note that urban centers of the Late Chalcolithic are strongly associated with dense patterns of small sites; large rural populations and cities are closely correlated. But they also address the issue of nonagricultural and noncontiguous hinterlands; based on site locations and excavated evidence for raw materials acquired over long distances, they propose the primary reason for the growth of LC cities was their importance as "hubs" in trade and political systems. This result dovetails with Menze and Ur's (2012) assessment of settlement potential, which shows the largest sites somewhat paradoxically near the southern edge of the Upper Khabur in areas of lower rainfall. However, these are near rivers and wadis. Higher precipitation areas at the Upper Khabur's northern edge have a dense pattern of small sites. And the central interface, between rivers and rain, had regularly spaced medium-sized sites. It appears that rivers were the greater enabling factor in urban growth than rainfall. River irrigation and canal transport have been proposed as the basis for early urbanism in southern Mesopotamia (Algaze 2001, 2008), but the importance of rivers clearly pertains even in areas of higher rainfall and no irrigation.

\section{Hollow Ways and Cities}

Rulers of southern Mesopotamian cities could physically express rural links and obligations through expansion of a controlled network of canals. Canals were an important expression of northern Mesopotamian empires in the first millennia BC and AD (Bagg 2000; Osborne 2015; Ur 2005; Ur and Osborne 2016; Wilkinson and Rayne 2010), but they were not yet a factor in the fourth millennium BC. Instead, roads may manifest rural-urban connections in the north.

A distinctive aspect of the northern Mesopotamian landscape is the pattern of radial lines surrounding many settlements. These radial lines ("hollow ways") can sometimes be observed on the ground, but they are clearer in satellite imagery that predates modern agriculture and deep plowing (e.g., CORONA imagery of the 1960s). Hollow ways are most often associated with secondary urbanism of the third millennium BC and intensification of agriculture; they were created when the daily movements of people and animals were constrained to narrow strips between maximally exploited fields (Wilkinson 1993). Trampling, wetting, and wind created a distinctive linear depression that retains water and supports lusher vegetation. Such features are usually c. 60-120 m wide and 0.5-1.5 m deep (Ur 2003).

Hollow ways have seen some of the densest analysis of any aspect of northern Mesopotamia (Casana 2013; de Gruchy 2016; Menze and Ur 2012; Ur 2003, 2009, 2010b, 2013; Ur and Wilkinson 2008; van Liere and Lauffray 1954/55; Wilkinson 1993, 2003; Wilkinson et al. 2001, 2014b; Wilkinson and Tucker 1995). Long hollow ways that connect settlements into strings of $50 \mathrm{~km}$ or more were presumably used for transport of traded materials and mid- or long-distance travel such as pilgrimage. Short radial hollow ways (3-5 km long) are evidence for a settlement's agropastoral system, connecting city inhabitants to fields or pasture or rural 
inhabitants to markets. Short hollow ways are often associated with "manuring," scatters of highly eroded sherds derived from the spreading of refuse on fields to increase crop yields. This model of movement and agricultural intensification works well for the region's third millennium BC secondary urbanism, but hollow ways are difficult to date and some may have developed in the fourth millennium $\mathrm{BC}$ during the initial urbanization of the region (de Gruchy 2016; Wilkinson et al. 2014b). In the Iraqi Jezira survey, Late Uruk sites were strongly correlated with hollow ways (Wilkinson and Tucker 1995, pp. 45-47). Further, creation and use of routes may long precede their archaeological visibility.

\section{Immigration and Urban Growth}

Surveys can reveal connections of cities to rural sites and hinterlands and also address mobility relevant to urban growth. For example, the Tell Brak Regional Survey collected data up to $15 \mathrm{~km}$ from the site to examine fluctuations in settlement patterns particularly relevant to urbanism. Brak expanded from 50-55 ha in LC2 to 130 ha in LC3 (Ur 2014; Ur et al. 2007, 2011). This growth was so rapid that it cannot be entirely from internal processes but must have involved significant immigration.

In LC2-3, Brak was the central site in a four-tier settlement hierarchy, which included towns of 5-7 ha, villages of 2-3 ha, and small villages of 1 ha or less (Wright et al. 2007, p. 10). These fourth millennium BC sites were not scattered randomly. The area north and west of Brak, up to c. $4 \mathrm{~km}$ from the site, was virtually empty of other sites in LC3; previously occupied sites in this zone were largely abandoned. Some sites on the east and south were closer to Brak (even as close as $2.5 \mathrm{~km}$ ), but notably most sites in these directions were on the opposite banks of the Wadis Jaghjagh or Radd from Brak. The population from the area emptied of villages likely fueled the rapid growth of Brak.

The evidence for immigration to Brak echoes that around the southern site of Uruk during its mid-fourth millennium BC expansion (Adams and Nissen 1972; Bernbeck 1999). Tell Brak at c. 130 ha is 18 times larger than the next largest site in its surrounding region (c. 7 ha; Wright et al. 2007). This ratio is similar to that between Uruk and its hinterland settlements in the Late Uruk period, although both Uruk (c. 250 ha; Finkbeiner 1991) and its next largest town (c. 15 ha; Adams and Nissen 1972) were larger.

The key difference between the Brak and Uruk situations is the distance from which the expanding city population was drawn; the near-empty band surrounding Uruk was 4 to $8 \mathrm{~km}$ away, and reduced settlement numbers in the Ur and NippurAdab regions suggest that more distant populations were drawn into Uruk (Bernbeck 1999). By contrast, the depopulated ring was only up to $4 \mathrm{~km}$ from Brak. The scalar difference in their sizes may be the reason for these different exclusion zones. There also was an increase in the number of settlements in the wider Uruk survey area, from 18 to 108, between the Early and Late Uruk periods (Adams and Nissen 1972, p. 11). Even if some new sites were created by newly settled herders, immigration into the region was a significant factor in overall urbanization. A similar regional 
immigration does not appear to have occurred in Tell Brak's hinterland, although the number of sites in the $15-\mathrm{km}$ ring surrounding Brak did increase from 82 in LC2 to 92 in LC3.

Other site-centered surveys across the Upper Khabur and Iraqi Jezira reveal significant variety in maximum site sizes and patterns. West of Brak, survey around Tell Beydar identified an increase in settlement numbers from Ubaid to LC2-3, but no site grew to urban scale (Ur and Wilkinson 2008). To Brak's east, the Tell Leilan Region Survey reconstructed significant numbers of sites in LC1-2, followed by a reduction of the smallest sites in LC3 as Leilan expanded. The impression given by the Leilan survey is of a three-step hierarchy of sites smaller than 5, 5-10, and larger than 10 ha, with four possible regional centers, including Leilan itself at around 15 ha (Brustolon and Rova 2007). Leilan probably expanded by drawing in population from nearby abandoned villages; this process is comparable to that in the Brak region, but it resulted in a flatter hierarchy with several large, but not massive, sites at the top.

The Tell Hamoukar survey, in northeastern Syria near the Iraq border, identified a similar pattern of increasing numbers of small LC1-2 sites, compared to the Ubaid period (Ur 2010b). The single massive site of Khirbet al-Fakhar (the Hamoukar Southern Extension) stands out as an anomaly. Its sparse but variable occupation extended for c. 300 ha but was short-lived, restricted to LC1-2 (al-Quntar et al. 2011). The low density of occupation at Khirbet al-Fakhar may reflect seasonal occupation by seminomadic groups (Wilkinson 2002), which could explain the negligible effect on nearby villages that might otherwise have been expected to supply its population. During LC3-4, Hamoukar itself reached c. 15 ha and Site 40 c. 8.5 ha, while the other sites in the region were smaller than 3 ha on average. The emptied-out settlement pattern around Brak is echoed more closely in the Iraqi Jezira survey, which was dominated by the 50-ha city of Tell al-Hawa in the fourth millennium BC (Wilkinson and Tucker 1995). The number of sites increased from the Ubaid to LC; sites of 2 ha or less dominated but were supplemented by a sitesize hierarchy of villages up to 5 and 5-7.5 ha. The area of 4-6 km around Tell alHawa itself was empty of LC sites.

\section{Agriculture and Pastoralism}

Northern Mesopotamia could sustain rainfall agriculture and produce high grain yields and has been identified as a core agricultural area (Lawrence et al. 2017; Wilkinson et al. 2014a). But near the 250-mm rain per year isohyet, there was wide annual variation, high-risk, and episodic drought (Jas 2000). Agriculture was the primary basis of the economy, but pastoralism provided a necessary supplement and may have dominated some subregions during bad years for farming.

At Tell Brak, we can examine the early urban economy. Barley and wheat were the primary crops in the mid-fourth millennium BC (Charles et al. 2010; Emberling and McDonald 2001, 2003; Hald and Charles 2008). Wheat decreased relative to barley from LC1-2, possibly reflecting early administrative control of cereals (Hald 2008). Smaller-scale crops include lentils, peas, bitter vetch, figs, and grapes, 
suggesting a thriving agricultural economy, with some administrative control of primary grains supplemented by domestic production of legumes and fruits. Using 100-150 people/ha, the estimated 5500-8250 inhabitants of LC2 Brak, at c. 55 ha, could have been supported by farming in a hinterland of $5 \mathrm{~km}$ radius immediately surrounding the site (Lawrence and Wilkinson 2015). However, the population of Brak at its 130-ha LC3 maximum $(13,000-19,500)$ would have demanded intensive cultivation of that area or expansion of farming beyond what could be walked in a day. The regional survey (above) indicates that some of the surrounding area had indeed been emptied by immigration into Brak, while the possible early hollow ways appear to reflect a strategy of intensive agriculture that enabled urban growth.

However, Styring et al. (2017) have shown that the intensive farming model is not upheld by in-depth analysis of botanical data. Carbon and nitrogen isotopes in LC3 grain and pulses from Brak reflect relatively low and variable manuring and an extensive agricultural regime. Further, the variability in isotope values in grain samples from a single LC3-4 house suggests that no single agricultural regime dominated; instead, flexibility and variety were employed to reduce risk. This risklimiting behavior is also expressed in the location of different crops: carbon isotopes indicate that barley was strategically grown in poorly watered areas, which it can tolerate, while wheat and other crops (pulses) were grown in well-watered areas (Wallace et al. 2015). Irrigation is not known in the region at this time, so well-watered wheat fields may have been near the Wadis Radd and Jaghjagh to the east and south. The potential use of these areas for wheat may explain the presence of small villages along these wadis, housing semispecialized wheat farmers. These pockets of intensive farming within a wider context of extensive farming suggest strategies appropriate to the overall marginal environment of Brak, which nonetheless offered richer microzones.

Sheep, goat, and cattle dominate LC faunal assemblages at Brak, followed by pigs and a small range of hunted wild animals. Culling strategies are still under study, but sheep were generally more common than goats (Emberling and McDonald 2001, 2003). Analysis of carbon and nitrogen isotopes of sheep and goat suggests a shift in grazing location from LC2 to LC3-4, toward suboptimal steppes (Styring et al. 2017). This fits well with the extensification of farming suggested by contemporary crop isotopes, which may have pushed herding farther from the city. Isotope studies reveal that the diet of LC Brak's human population involved less than $20 \%$ animal protein and was dominated by grain (Styring et al. 2017), an unsurprising proportion that reflects the value of herd animals for secondary products, not meat. Textiles were essential to the political economies of southern Mesopotamian and western Syrian cities in the third millennium BC; textiles may also have been crucial for the success of earlier northern Mesopotamian cities.

The main challenge to a strong role for textiles in the fourth millennium BC economy is dating the shift from hairy to wooly sheep, which only occurred many generations after domestication. Art and texts from the Late Uruk period in the south (c. 3200 BC) show or refer to wooly sheep and suggest the shift had taken place by then, but the nature of sheep in the north in the mid-fourth millennium BC is still a question (McCorriston 1997). Fleece may have been exploited as early as the Pottery Neolithic (Helmer et al. 2007), and there is proxy evidence that this shift was 
underway by the fifth millennium BC Ubaid period. Spindle whorls from Tell Kosak Shamali on the Upper Euphrates in Syria and Telul eth-Thalathat II in northern Iraq exhibit a trend toward lighter weights from the Ubaid through LC3, suggesting that a shift from flax to wool had commenced. This trend is supported by an increase in the percentage of older sheep across the same periods (Sudo 2010). Sheep became more common at Tell Zeidan on the mid-Euphrates at the same time (Stein 2012). Spindle whorl dimensions and weights also moved toward a standardized size that is optimal for wool from LC2 to late LC3 at Brak. Large quantities of flax seeds were recovered in storage facilities in LC3 Brak (Hald and Charles 2008, Charles et al. 2010), but the primary product may have been their oil. The accumulated evidence suggests that the contribution of textiles to the economy of the north grew during the fourth millennium BC.

\section{Noncontiguous Hinterlands}

Resource systems of early cities were not based solely on connections within walking distance but included far-reaching "dendritic" systems. Pastoral resource systems, which in some seasons needed to avoid space used for agriculture, may have been particularly extended (Zeder 2003). And networks that drew in exotic raw materials extended farther still to the north and east. At Grai Resh in northern Iraq, evidence for long-distance trade beyond northern Mesopotamia includes objects of obsidian, lapis lazuli, and carnelian (Kepinski 2009, 2011). LC tombs at Tepe Gawra included objects of silver, electrum, serpentine, and marble (Rothman 2002). LC3 houses at Tell Brak contained objects of silver, gold, amethyst, rock crystal, lapis lazuli, and alabaster (Emberling 2015; Emberling and McDonald 2001, 2003; Oates and Oates 1993). Obsidian is particularly frequent at LC2-3 sites; obsidian sourcing analysis reflects extended acquisition networks reaching into central and eastern Turkey.

The inhabitants of LC2 Tell Hamoukar, for instance, participated in a network of obsidian acquisition connected to the Anatolian sources of Bingöl and Meyan Dağ (Khalidi et al. 2009). The dominance of Bingöl obsidian in the lithic assemblage may reflect a direct relationship with the source. The sheer quantities of obsidian blades and debitage on the surface of Hamoukar's Southern Extension, together with cores from excavations, suggest that the site was a center for obsidian import and tool production, with unhindered access to its source.

By contrast, at Tell Brak, obsidian tells a complex story of the site's looser connection to Anatolian sources, more unpredictable access to obsidian, and mixed use for utilitarian and luxury items, including tools, inlay, and vessels. Geochemical characterization of LC2 obsidian from Brak indicates a connection to the Bingöl B sources of the eastern Taurus but also exploitation of Nemrut Dag and Lake Van/ Meyan Dağ (Khalidi 2014; Khalidi et al. 2009). The variety of obsidian, in form and source, as well as careful reuse of obsidian, suggest relatively low intensity of contact. The variety of obsidian sources and intensity of production further reduced in LC3, while use of chert increased. Obsidian was a key commodity, present at many other LC sites as beads, blades, vessels, cores, and debitage, but geochemical 
sourcing elsewhere is limited (although see Kopanias et al. 2013 for Ubaid-LC1 obsidian from Tell Nader).

\section{Site-Scale Themes in Urbanism}

\section{Northern Mesopotamian Sites}

Excavations of LC sites in northern Mesopotamia include single period and multiperiod settlements and allow us to address positive aspects and challenges of northern Mesopotamian urban life directly. For LC1, the sites include Hammam at-Turkman (Akkermans 1988), Tell Zeidan (Stein 2009, 2010, 2011), Tell Mashnaqa (Beyer 1998), Tell Feres al-Sharqi (Baldi 2012; Forest and Vallet 2008), Tell Brak (J. Oates 2012), Tell Leilan (Schwartz 1988b), Tell Hamoukar (Abu Jayyab 2012), Tepe Gawra (Rothman 2002, 2009; Tobler 1950), and Nineveh (Gut 1995). In Iraqi Kurdistan, there is an important older LC1 excavation at Qalinj Agha (al-Soof 1969; alSoof and El-Siwwani 1967; Hijara 1973). Newer excavations of LC1 sites are beginning to supplement our information on this region: Helawa (Peyronel and Vacca 2016; Peyronel et al. 2016) and Surezha (Stein et al. 2015). Late Ubaid-LC1 materials are known in southeastern Turkey from many sites, such as Kenan Tepe on the upper Tigris River (Creekmore 2007; Parker et al. 2006, 2008). However, because Anatolia remained nonurban in the fourth millennium BC, I concentrate here on the region south of the Taurus.

Excavations of LC2 include many of the same sites: Hammam et-Turkman, Tell Zeidan, Tell Mashnaqa, Tell Feres al-Sharqi, Tell Brak (J. Oates 1986), Tell Leilan, Tell Hamoukar, Grai Resh (Kepinski 2011), Nineveh, and Tepe Gawra, and in Iraqi Kurdistan, Qalinj Agha, Helawa, Surezha, Tell Baqrta (Kopanias et al. 2016), and Tell Nader (Kopanias et al. 2013). The latter excavations suggest that Kurdistan was culturally connected to regions farther west at least through the LC2. The architectural traditions, glyptic, and ceramic assemblages closely match those of the Ubaid and LC1-2 of the Iraqi Jezira and Upper Khabur, and obsidian was common (al-Soof 1969; Beuger 2016, Peyronel et al. 2016). Many of the same multiperiod sites were occupied during the LC3: Tell Brak (J. Oates 1985), Tell Mashnaqa, Tell Mozan (Kelly-Buccellati 2010), Tell Leilan, Tell Hamoukar, Grai Resh, Tell al-Hawa, Tepe Gawra, and Nineveh. In Iraqi Kurdistan, occupation of Tell Nader, Surezha, and Helawa persisted.

Based on excavations and surveys, the LC4 influx of southern influence across the Iraqi Jezira and Upper Khabur caused disruption to sites and settlement patterns: LC3 cities such as Tell Brak contracted rapidly, and destruction levels appeared at both Brak and Hamoukar. In Kurdistan, some sites were abandoned, e.g., Helawa and Tell Nader, although others such as Gurga Chiya embraced southern Mesopotamian influence (Wengrow et al. 2016). The presence of LC4-5 southern Uruk pottery in Kurdistan is patchy-limited in the Upper Tigris but sporadic in the area immediately around Erbil, the eastern bank of the Greater Zab River, the Rania Plain of the Lower Zab, and the upper reaches of the Adhaim River (Iamoni 2016; Kolinski 2016; Skuldbøl and Colantoni 2016; Tomé et al. 2016). 


\section{Settlement Size and Form}

Site surface collections are important hinges between regional surveys and excavations. The two best-known cities of northeastern Syria, Tell Brak and Tell Hamoukar, have been partly identified as such through site survey. Structured surface collections of both sites used the same methodology of grids $100 \mathrm{~m}$ per side, within which squares of 10 x 10 m were intensively collected (Ur 2002b, 2010b; Ur et al. 2011). Based on less structured survey and excavations, additional LC2-3 urban settlements include Tell al-Hawa, Grai Resh, and, possibly, Nineveh, Tell Leilan, and Tell Mozan.

\section{Tell Hamoukar and Its Southern Extension}

Tell Hamoukar, at the eastern edge of the Upper Khabur, is unique in size and morphology. The main mound has two distinct areas, a high mound and a lower town; these grew to 105 ha in the third millennium BC, but only c. 15 ha of the high mound were occupied in the LC (Ur 2002a, b, 2010b). Hamoukar's Southern Extension (Khirbet al-Fakhar) was established in LC1 and reached c. 300 ha in LC2. Instead of forming a ring around a core mound, the Southern Extension is uniquely and entirely located south of the core. The Southern Extension was not occupied beyond the end of LC2, and subsequent LC3-5 settlement at Hamoukar was restricted to the main mound. The reasons for contraction in settlement size in the LC3, when Brak was growing rapidly, are unclear. Excavations on the main mound uncovered several LC3 building complexes with evidence for sophisticated administration of stored goods (Gibson et al. 2002; Reichel 2002).

The LC1-2 very large, low-density settlement is in stark contrast to expected settlement size and form for this region. A size of 100 ha has long been assumed to be the maximum that the northern plains could support, until the artificial imperial capitals of the Neo-Assyrians (Wilkinson 1994). At three times that maximum, and disconnected from its associated mounded settlement, Hamoukar's Southern Extension presents an unexpected challenge to our assumptions.

\section{Tell Brak and Its Outer Town}

At Tell Brak, excavations since the 1930s and more recent survey give us an unparalleled multiscalar view of its urban nature. Brak has one of the largest and tallest mounds in northern Mesopotamia, c. 50 ha of horizontal extent and more than $40 \mathrm{~m}$ tall, although only c. 15-20 m tall during the fourth millennium BC, based on elevations of LC levels in excavations. This core mound is surrounded by a lower area of settlement, outlined by a "corona" of small mounds at its edge. The latter two areas are termed the "outer town." After frequent but random inspection and surface collections since the 1970s, the first dedicated assessment of Brak's urban landscape was made in 1998 (Emberling et al. 1999). Soundings in the outer town gave the first hints of the extent of settlement in the fourth and third millennia $\mathrm{BC}$ in particular 
(Skuldbøl 2009). Following these soundings, from 2002 through 2006, the Brak Suburban Survey explored the site's expansion and contraction through intensive collection of surface materials across the outer town.

The results of the suburban survey are dramatic (Ur 2014; Ur et al. 2007, 2011). Occupation in the outer town began in LC2, represented by sherd scatters on the north, northeast, and southwest. The sherd scatters later became the small submounds of the site corona. LC2 Brak is estimated as 55 ha of discontinuous settlement, including the central mound and these outer-town scatters. In LC3, the outer town rapidly formed a solid arc around the core mound from north to southeast, with additional significant occupation on the south and southwest. Brak, which reached 130 ha in extent, comprised a central densely occupied core mound of c. 55 ha, a ring of smaller submounds of 1-4 ha each, located 200-500 $\mathrm{m}$ from the core, and an area of low-density occupation between core and ring. This form is less surprising than that of Hamoukar, but the varied occupation density and the small mounds at the site edge are unusual features. Brak also was larger than might be expected.

Brak underwent an equally dramatic depopulation in LC4, contemporary with the Uruk expansion. The outer town was abandoned, and there is evidence for burning of many final LC3 levels on the central mound, plus replacement of local traditions with southern ones. These changes include reorganization of the Eye Temple plan in southern style and its potential rededication to the southern goddess Inanna (Emberling 2002, p. 86). This decrease in size suggests that the southern presence at the site may have destabilized Brak's economy, whether through positive opportunities for movement elsewhere or negative demands that encouraged urban flight. Alternatively, contemporary small-scale climate changes or environmental challenges may have contributed to this depopulation.

Late Chalcolithic occupation on Brak's core mound has been explored in seven distinct excavation areas, generating chrono-stratigraphic sequences of material culture and in-depth examination of architecture. Numerous preliminary and final reports reflect the intensity with which this period has been explored (Emberling et al. 1999; Emberling and McDonald 2001, 2003; Matthews 2003; McMahon 2013; McMahon and Oates 2007; D. Oates 1985, 1987; D. Oates and Oates 1991, 1993, 1997; J. Oates 1985, 2005; J. Oates et al. 2007). Soundings and excavations in the outer town add data about the LC3 settlement expansion (McMahon et al. 2011; McMahon and Stone 2013).

\section{Other Urban Sites}

Additional LC sites can be identified as cities, based mainly on their size and form. Tell al-Hawa reached 50 ha during the first half of the LC. Surface survey identified a core densely occupied mound of 18 ha, with a diffused outer town of 32 ha to its east, southeast, and south (Ball 1990; Ball et al. 1989; Wilkinson and Tucker 1995). Based on survey, the maximum size was attained early in the Uruk period (LC2-3), with a contraction to the main mound in Late Uruk (LC4-5). The intensity of LC3 occupation varied; an area south of the main mound had notable quantities of sherds, flint, and obsidian, while other areas were less dense. Limited excavations recovered LC2-early LC3 pottery and obsidian blades at the eastern edge of the outer town 
(Ball et al. 1989). In growth and morphology, Tell al-Hawa thus closely parallels contemporary developments at Brak. Although smaller than Brak, it nonetheless stands out among other sites in its region, most of which were smaller than 1 ha.

Grai Resh is located just south of the Jebel Sinjar, in an advantageous location on east-west trade routes and at the northern end of the Wadi Tharthar, a north-south watercourse parallel to the Tigris Valley. Grai Resh covers c. 32 ha, including a high mound and lower town to its west and south (Kepinski 2009, 2011). Like Tell al-Hawa, Grai Resh is smaller than Brak but is still significantly larger than most sites in its neighborhood. The position of its outer town on one side of the high mound is related to local topography, including adjacent wadis. LC2 and LC3 levels on the high mound included large buildings used for workshops and perhaps administration.

Excavations at Nineveh focused on the Neo-Assyrian palaces, but deep soundings revealed Late Chalcolithic occupation, which has been estimated at 40-45 ha in extent (Stronach 1994); its morphology is uncertain. Two other sites in the upper Khabur provide limited data. Excavations at Tell Mozan concentrated on the later third millennium BC, the period of its political importance as the capital Urkesh. Late Chalcolithic materials were, however, recovered in a deep trench (Kelly-Buccellati 2010). The size of LC Mozan is unknown, but its third millennium BC prominence may be related to earlier urban status. A step trench at Tell Leilan exposed an unbroken sequence of occupation layers from Ubaid through Early and Late Uruk, LC1-5; the trench location at the site edge may account for the limited architecture (Schwartz 1988b). Like Mozan, the extent of LC settlement at Leilan is unknown, but it may have been c. 15 ha.

\section{Rural Sites and Villages}

If cities are organizing forces, we should see their impact on the landscape: bending trade routes, absorbing rural populations, and affecting adjacent settlements. Cities cannot survive without the subsistence, resources, and labor provided by hinterlands and rural sites. But some small sites in northern Mesopotamia confound assumptions about ruralism. While early cities absorbed some village populations and tied other villages close with economic interconnections, other small sites seem unaffected by nearby urban growth or even echoed traditionally urban functions and activities at smaller scales. Our excavations of rural and small sites are limited, however, despite the hundreds of small sites identified in regional surveys.

Tell Feres al-Sharqi is a small LC site of 4 ha, located $8 \mathrm{~km}$ north of Brak. At that distance, it should have been within Brak's economic and political sphere of influence. Excavations uncovered occupation across LC1-4 (Forest and Vallet 2008). The earliest levels had large, well-planned structures of late LC1; walls 1-m-wide outlined rooms, one at least $8 \mathrm{~m}$ long by $6 \mathrm{~m}$ wide, with postholes for two rows of roof-support columns. The columns reflect an ambitious room width greater than available timber could support. The excavators suggest a secular community function. The next levels are characterized by kilns and multiroom, irregular granaries, followed by an LC2 building with engaged pillars on its façade, which the excavators interpret as a second communal use building. After an LC2-3 gap, another 
grain-storage building was built in LC4, followed by a later LC4 large (over $230 \mathrm{~m}^{2}$ ) multiroom compound with a tripartite suite, pillared room, and courtyards, partly constructed in fired brick. This final building complex has been interpreted as "une grande résidence rurale" (Forest and Vallet 2008, p. 193). The presence at Tell Feres of imposing residences and grain-storage facilities suggests that wealth accumulation and political activity were not confined to urban settlements. This site's function and reach parallels Tell al-Raqa'i in the third millennium BC, a 0.4-ha site that nonetheless had a shrine and large grain-storage buildings (Schwartz 2015).

Tell Mashnaqa on the Middle Khabur was a traditional 4-ha village for most of its occupation (Beyer 1998). A series of tripartite buildings and circular ovens belong to LC1-2. These were followed by a terrace in LC3, supporting traces of what the excavators interpret as an official building, accompanied by large ovens over $2 \mathrm{~m}$ in diameter. This site may be similar to Tell Feres in its para-household local power, but in this case in an area with no cities nearby.

In northern Iraq, Tepe Gawra is another small site with a complex economy, religious power, and extensive trade connections. The site was only c. 1.5 ha, but by LC2, the settlement included a temple, public building, and sophisticated resource administration implied by container sealings. These aspects expanded further in LC3, with the development of a central warehouse and tighter administration (Rothman 2002, 2009; Rothman and Peasnall 1999; Speiser 1935; Tobler 1950). Obsidian blades (Speiser 1935, pl. XXXVIII; Rothman 2002, p. 62) reflect Anatolian connections throughout LC1-3, and large cores in LC3 levels reflect onsite obsidian crafting. Obsidian vessels and silver objects in LC2-3 graves express inequalities through the accumulation and conspicuous consumption of wealth.

Although on the northwestern edge of northern Mesopotamia, the 4-ha Anatolian site of Arslantepe adds further evidence for the complexities of economy and authority in small sites in the fourth millennium BC. In LC3-4, elite residences, a temple-palace complex, large-scale storage, administration of goods, and massproduced ceramics reflect specialization and hierarchies of wealth and power (Frangipane 1994, 2012, 2016, 2018; Vignola et al. 2014). Small settlements, like cities, could house ritual and administration (Frangipane 2009; Rothman 2009). Ruralism clearly must be explored further.

\section{Urban Demography and Urban Dwellers}

Past urban population density remains difficult to assess accurately. Excavations at LC sites in northern Mesopotamia have revealed public buildings (e.g., Tell Brak's Eye Temple; Mallowan 1947) and single houses or small groups of buildings (e.g., Tell Hamoukar Area B; Gibson et al. 2002). However, our limited knowledge of neighborhoods creates an intractable problem in assessing population numbers. This is particularly frustrating since large and dense population is a widely cited trait of ancient and modern cities (Glaeser 2011; Sudjic 2016). Common estimates for Mesopotamian settlements range from 100 to 200 people per ha (Wilkinson 2000), a $100 \%$ difference that can result in population numbers varying by many thousands. Postgate (1994) argues plausibly for an even wider range, 248-1205/ha for Abu 
Salabikh, a southern Mesopotamian town in the mid-3rd millennium BC. Population size and density are therefore too imprecise to use effectively for city definition. Low-density urbanism is a further challenge for simplistic definitions of ancient cities based on demographics (Evans et al. 2007; M. E. Smith 2010). Emphasis on "population" also risks treating the group as the minimal unit, rather than acknowledging that cities are occupied by unruly individuals, who are poorly characterized as "demography." Complexity and interconnectivity of human relationships and a high frequency of interactions are thus more appropriate urban traits.

Agent-based modeling (ABM) is a growing method in archaeological research (Cegielski and Rogers 2016) and provides a bottom-up approach to urbanism with people and their interactions at its heart. At their best, applications of ABM visualize the impact of individual decisions, small changes, and larger unpredictable disruptions such as climate change (Batty 2013). ABM studies in Mesopotamia so far have focused on city-states of the second millennium BC or empires of the first millennium BC (Altaweel 2015), but the choices and variables in play are relevant to the earliest cities as well. ABM can include the negative variables of conflict or corvée labor and the positive variables of religious attachment and belonging to place, both of which were relevant to our earliest urban population agglomerations. The Modeling Ancient Settlement Systems (MASS) project used ABM modeling to address cities of the fourth-third millennia BC in northern and southern Mesopotamia (Wilkinson et al. 2013). Although this project used individual "person objects," the primary decision-making unit was set at the household, and the decisions explored were medium- to long-term issues of food production and exchange capacity. The authors' aim to outline emergent behavior or patterns was an acknowledged characterization of people as logical, rational, decision makers. It is useful to balance this with seeing them as women, men, or children walking, working, and playing, whose daily activities and desires may be, economically speaking, irrational. De Gruchy's (2016) exploration of northern Mesopotamian intrasettlement routes reminds us that optimal choices at the individual level need not be the easiest, shortest, or quickest. Alternate goals, such as social connections, may drive movement and decisions.

The type of household typical of new urbanites remains a question for the future. Village households were probably composed of multigenerational families with large numbers of children, adapted to the labor demands of subsistence agriculture. But new ways of urban working and interacting may have supported and been enabled by new household arrangements: smaller numbers of children, fewer cohabiting generations, or households of unrelated individuals of the same age and occupation. Our limited evidence thus far suggests the tripartite houses of the fourth millennium BC in the south were twice as large as those of the north (Frangipane 2018). But excavations have not so far revealed enough houses of the fourth millennium BC to address this issue conclusively.

\section{Urban Authority and Leadership}

Mesopotamian history, with its charismatic kings (e.g., Naram-Sin of Akkad in the third millennium BC) and powerful imperial leaders (e.g., Ashurnasirpal II of the 
first millennium BC), casts a long shadow over our reconstruction of leadership in the fourth millennium BC. These rulers governed by a powerful combination of personal strength, connection to the gods, and tightly knit, loyal bureaucracies. They also had centuries or even millennia of tradition in support of their ideology and actions. But such traditions were not available to leaders of the earliest cities, and our evidence for deities and the depth of bureaucracy in the fourth millennium BC is thin. Blanton and Fargher's (2008) questioning of coercive power is relevant to examination of how early Mesopotamian rulers ruled. Why might rural communities tie themselves to cities in the early fourth millennium BC? Did city dwellers make rational choices to belong to cities, or did cities grow so gradually that city membership was simply an unconscious result?

Presence of a form of authority or institutions is frequently used to identify a city and is equally important for the successful operation of an urbanized system. In fourth millennium BC northern Mesopotamia, religious and secular institutions are identifiable, but individual leaders within these institutions are difficult to identify. We therefore cannot answer whether these buildings represent coercive power or collective action (Blanton 2010; Blanton and Fargher 2008).

\section{Religious Institutions}

The Eye Temple at the southern edge of Tell Brak's core mound is northern Mesopotamia's best-known religious institution of the fourth millennium BC. The precise dating of its sequence of rebuildings is uncertain, but its four phases are contemporary with Brak's urban growth: an initial Red phase, a Gray phase, a White phase, and a final Red phase (Emberling 2002; Mallowan 1947, pl. LVII). The phases were labeled after their distinctive brick or plaster colors. Clay cone mosaic decoration in the final phase aligns it with the Late Uruk Eanna IV buildings at Uruk itself, so an LC4-5 date is probable, contemporary with southern Uruk presence. But the initial development of the temple and any associated leadership occurred prior to southern influence.

The Gray phase of the Eye Temple provided the majority of the thousands of "eye idols" from which the temple derives its name. Elsewhere, eye idols have been recovered from LC2 and LC3 levels in Area TW at Brak (Oates and Oates 2002; personal observation 2011), and in LC3 levels at Hamoukar (Gibson et al. 2002). Stamp seals from the Eye Temple resemble a sealing assemblage from LC3 rubbish in Brak's outer town and seals from an LC3 pit at Tell Hamoukar (Gibson et al. 2002) and from contemporary levels at Tepe Gawra and Hacinebi (Emberling 2002; Pittman 1999). These materials reinforce an LC3 presouthern-contact date for the Gray phase. The initial Red phase below it thus could be LC2 or even earlier.

The final Red version of the temple's platform was at least $26 \mathrm{~m}$ wide by c. $65 \mathrm{~m}$ long and $3 \mathrm{~m}$ tall. This scale reflects the accumulation of raw materials and management of a significant labor force, even before the temple building was added. The horizontal extent of the earlier platforms is unclear, but they ranged from $60 \mathrm{~cm}$ to $1 \mathrm{~m}$ tall, evidence for the gradual development of religious power in LC2-3 (and perhaps earlier). The building's frequent renewals may also reflect this power and the integrating effect of community action. Late Uruk levels of Uruk's Eanna 
complex are notable for the razing of still-usable temples and other buildings, followed by new structures, an expression of power that could control people's labor and create employment. Brak's Eye Temple is smaller than Uruk's Eanna complex, but the rebuilding and expansion of its platforms would have been a comparable ongoing, high-visibility project.

Temple gifts reflect further community investment. Each eye idol or stamp seal was not inherently very valuable; they are small, their material (usually limestone) is available nearby, and they require minimal skill to make. But the aggregate of thousands of figures, seals, and amulets within a relatively short period of time may reflect a widespread and tenacious connection with many individuals. Ritual events open to the whole community may have reinforced this connection and support an interpretation of collective action. There are no unequivocal images of leaders or deities from the Eye Temple, forcing the use of "religious leadership" and "religious power" in our discussion, rather than the power of individual agents (priests or priest-kings).

Tepe Gawra is the only other site in northern Mesopotamia that has clear religious institutions. A small tripartite temple, c. 10 x $10 \mathrm{~m}$ with a deep porch entrance, was at the eastern edge of the site in LC1-2. It faced outwards, suggesting its connection to villages and nomadic peoples beyond Gawra itself (Rothman 2002, 2004). Temples of similar plan persisted in LC2 in the center of the site, and a temple at the southeastern edge carried on the tradition in LC3. Unlike the Eye Temple at Brak, the Gawra temples were not locked into the same location but shifted within the settlement over time. This aspect of the Gawra temples may be related to the site's small-scale and flexible use of space; it may also reflect a limited, informal power for the institution.

Questions about these religious institutions remain: Was the labor in temple construction freely gifted or compelled? Did labor involve all inhabitants of the settlement equally? Were inhabitants of surrounding settlements linked to the temple's system of rights and obligations? This question is especially pertinent since both urban (Brak) and nonurban (Gawra) settlements had secular institutions that might have competed or collaborated.

\section{Secular Institutions}

Early excavators were tempted to label every large building a temple (e.g., Speiser 1935), but recent excavators are cautious, taking into account building plans, internal features, and contents. Nonreligious public buildings are found in cities and smaller settlements. At Brak, a secular institution was founded at approximately the same time as the Eye Temple, in LC2, which adds complexity to the examination of urban leadership. This secular institution is at the northern edge of the main mound, adjacent to an entrance to the city's core. Excavation in this area revealed a 12-m depth of continuous layers from LC2 to LC5 (Emberling et al. 1999; Emberling and McDonald 2001, 2003; McMahon and Oates 2007; Oates and Oates 1991, 1993). The "Basalt Threshold Building" (BTB) was first exposed in 1997 (Emberling et al. 1999; J. Oates 2005; Oates and Oates 1997). 
Originally thought to be a city gate, it was later revealed to be a monumental building with a large doorway near its northwest corner.

This building has walls $1.85 \mathrm{~m}$ thick and large rooms at least $4-5 \mathrm{~m}$ wide and $6 \mathrm{~m}$ long. These measurements are similar to the (later) final Red phase of the Eye Temple, with its c. 2-m-wide walls and side rooms 4.5-5.0 m long. The threshold slab of the BTB measures 1.85 by $1.52 \mathrm{~m}$ and is almost $30 \mathrm{~cm}$ thick, or over $2500 \mathrm{~kg}$. There is an open courtyard to its north; the mudbricks are reddish clay that contrasts with the gray mudbricks of structures nearby. The unique brick matrix and the building's large scale-far larger than domestic or industrial buildings - together suggest an investment in labor and the aim of high visibility. It remained in use until early LC3 and was then cleaned out and intentionally filled with mudbricks, which erased clues to its function but imply the building's special nature. We do not have many contemporary monumental structures in northern Mesopotamia for comparison, but the building lacks the symmetry and decorative materials of a temple. A secular administrative function is plausible.

The BTB overlooked industrial structures and features to its west, where basic and luxury goods were produced. Clay container sealings from this area (McMahon and Oates 2007) suggest that administration of raw materials and manufactured goods took place there. The close physical association of the BTB and the industrial facilities supports the control or oversight of resources and facilities by the users of the BTB. Like the invisible priests of the Eye Temple, the users of the BTB remain largely unknown. Products may have been sold in a market or redistributed to wholly dependent clients.

After the BTB was filled, a "feasting building" continued some of the public functions in this area in LC3 (Emberling et al. 1999; Emberling and McDonald 2001, 2003; Oates and Oates 1997). This building was also associated with container sealings, while ovens, a grill, large amounts of fragmented bones of sheep, goats, and cattle, and ceramic plates were recovered from the courtyard to its north. The processing, cooking, and discarding of animal bones has a "feasting signature" including valuable animals and whole carcasses (Weber 2014). This signature is distinct from that of redistribution, which should involve cheaper animals and smaller cuts. Like the BTB, the feasting building was eventually deliberately filled with clean soil. Its scale (10 x $10 \mathrm{~m}$ with additional courtyard), formal central room, and niching and buttressing suggest that this was an audience hall for a local leader (see also Emberling 2015).

Similar secular institutions are present at other urban and smaller sites. At Grai Resh, an LC3 level on the high mound had a brick-filled platform for a tripartite building comparable to Brak's feasting building (Kepinski 2009, 2011). At Tepe Gawra a thick-walled, nondomestic "building with military and social functions" (Rothman 2004, p. 86) was located at the northern edge of the site in LC1-2. It was slightly larger (c. $11 \times 12 \mathrm{~m}$ ) and of the same high visibility and prominence as the contemporary temple on the east. Additional thick-walled public buildings were exposed in the site's southwest. In the LC3, a storehouse associated with sealings implies centralized administration, and another public building occupied the site's northeast. These buildings have very mixed contents, suggesting 
a combination of manufacturing, defense, and feasting; they may have been residences of leaders or corporate gathering places (Rothman 2002).

The presence of separate religious and secular institutions at Brak and Gawra contrasts with what we know of fourth millennium BC Uruk in southern Mesopotamia, where the temple complexes were so extensive that it is difficult to see how there would be any space (physical or ideological) available for a distinct secular power. Although the functions of many buildings in the Eanna complex are not clear (e.g., Palace E, Great Court, Riemchen Building), they are in close association with others (Building A) that are temples, and the building on the Anu Ziggurat is surely a shrine. This complex is largely responsible for a "temple first, palace second" model for southern Mesopotamian power, urban growth, and urban landscapes. In contrast, the contemporaneity of entirely separate religious and secular institutions at Brak and Gawra may be evidence for a distinctively northern Mesopotamian duality of power. The relationship between these institutions, and whether they were complementary or competitive, is one of the most intriguing aspects of Brak's urban development. The parallel presence of two similar institutions at the smaller site of Gawra reinforces the complex nature of urbanization and problematizes the concept of ruralization. These institutions together reflect the permanence of leadership and growing power inequalities in the early fourth millennium BC. At Brak, they were physically separated on either side of the core mound, suggesting that their spheres of action also were separate. This duality raises the issue of competition for the time, labor, products, and loyalty of Brak's inhabitants.

\section{Production and Value}

\section{Pottery Production}

LC1-5 ceramic assemblages at sites across the Upper Khabur and Iraqi Jezira are extremely similar, reflecting strong links between these zones. Specific types from the LC subphases have wider parallels with southeastern Turkey to Iraqi Kurdistan. These LC regional connections have been extensively discussed elsewhere (Helwing 2000; Marro and Hauptmann 2000; Rova 1999-2000; Trufelli 1997); the key aspect of ceramics for the study of urbanism is the specialized, cost-effective technology these assemblages represent. There also is evidence at some sites for the clustering of production in dedicated workshops or industrial areas.

A trajectory toward regional standardization of ceramic forms is already seen in LC1 to early LC2. By LC2, the assemblages of Brak and Hamoukar match very closely in terms of forms and surface treatments (al-Quntar et al. 2011; al-Quntar and Abu Jayyab 2014). Coarse, rapidly made bowls (wide flower pots) form a significant percentage of LC2 ceramic assemblages across the region, although more time-consuming types such as burnished hole-mouth jars and fine ware vessels with stamped decoration also were present. Mass production of pottery expanded in LC3; the number of different types was reduced further, forms were extremely standardized with limited variation in shape or dimensions, and surface treatment declined. Corrugated-rim jars and large bowls with "hammerhead" rims were common, and 
even fine wares lost their stamped decoration. The dominance of coarse chaff temper in LC3 also indicates rapid production; chaff allows vessels to dry more quickly than mineral temper (dominant in LC2) and reduces firing costs and manufacturing time.

The increased use of chaff in LC3 ceramics dovetails with storage of chaff at Brak in LC3 levels (Emberling and McDonald 2003; Hald and Charles 2008). Chaff is also a key element of dung-cake fuel, mudbricks, and mud plaster, the demand for all of which would have increased with urban needs for more cooking and housing. Aggregated populations thus created high demands for chaff from their hinterlands, as well as for food and other resources. Chaff, usually thought of as a waste product, thus may have become a valuable managed resource in early cities.

\section{Manufacture and Use of Luxuries}

An expansion in vertical hierarchy is expressed in LC2-3 contexts through increased import of precious materials and manufacture of luxury objects. Many of these luxury items were relatively small but nonetheless highly visible when worn or carried: beads, pendants, inlay, and vessels. Lapis, amethyst, rock crystal, electrum, gold, and silver are present in small but significant quantities in many northern Mesopotamian sites. Obsidian uniquely straddles value categories. Obsidian blades and cores are common on LC2-3 sites, and use wear indicates that obsidian was a practical material for many quotidian tasks. But obsidian also was made into luxury items. At Brak, a cup made from a repurposed obsidian core on a marble base is an example of elite signaling (Khalidi 2014; McMahon and Oates 2007), which reflects the growth of inequality by late LC2. There are serpentine and marble bowls and two polished spouted vessels of obsidian in Tepe Gawra late LC2 tombs (Tobler 1950, p. 82). The glassy nature of obsidian makes it particularly hard to work. The intrinsic value of the imported material was significantly supplemented by the time and skill in crafting.

Obsidian beads are common at Brak in LC2-3 contexts, in graves, in debris, and in various stages of manufacture within LC2 workshops. Grai Resh has identical obsidian beads (Kepinski 2009, 2011), and similar beads are present in Tepe Gawra tombs. In Brak graves, they are often found together with white shell or frit beads, the contrast between black and white making a striking and eye-catching display. Obsidian disks and mother-of-pearl lozenges echo this black and white theme in inlaid objects. Like eye idols, these are small objects of low individual value that nonetheless would have physically marked status and wealth when accumulated and displayed. However, the production of high-value items for elites was far smaller than the scale of production of basics, and there was significant overlap in production location of these divergent items.

\section{Production Location}

Workshops are known from many LC sites across northern Mesopotamia, including cities and villages. While this indicates that manufactured goods were not exclusively produced in cities, there are contrasts in production locations. Tepe Gawra has workshops or activity areas for pottery, weaving, and woodworking; but at this small 
site such spaces appear to be flexible, collective, and subject to minimal control. Significant numbers of crafting tools were recovered from houses. At Grai Resh, an LC2 building included a room used as a workshop for producing obsidian beads, but the limited area of excavation makes it difficult to place this within the larger urban landscape.

At Hamoukar's Southern Extension, distinctive pressure-flaked blades demanded skill and reflect the presence of specialized knappers. Workshop production of obsidian tools is indicated by concentrations of cores, blades, and debitage, but workshops were located within or near houses (al-Quntar et al. 2011). Retouch and chipping indicate that the tools were used as well as produced there, potentially for the manufacture of organic objects or pottery. Production of textiles may also have taken place in the same houses. The mix of crafting and possible pastoralism reflects a particularly flexible economy.

In contrast, at Tell Brak there is evidence for administration or oversight of clustered production. Area TW presents a sequence of increasingly formalized crafting areas, overseen by users of the BTB. The space west of the BTB changed during LC2 to early LC3, from a crafting zone with ephemeral structures, to a large workshop building with a courtyard, kilns, and ovens, ultimately to a massive industrial building with large kilns, basins, grinding stones, and storage (McMahon and Oates 2007). Pottery production dominated but manufacture of other basics and luxuries is represented: flint and obsidian tools, beads, stone and shell inlay, stone vessels, and possible wooden objects. Ovens reflect the cooking of large amounts of bread and meat, possibly for workers but potentially for redistribution or sale. Spindle whorls provide indirect evidence for thread, string, or textile production, and textiles may be basics or luxuries depending on skill, elaboration, or dyeing. The physical connection between industries and the BTB suggest institutional management of production and products.

Institutional oversight reflects positive and negative aspects of urbanism: opportunities for employment counterbalanced by loss of personal choice in the timing and intensity of work. The combination of basic and luxury goods' production within the same workshops at Brak is intriguing. The clustering of industries that made basics such as pottery, tools, and food is efficient in terms of economies of scale. The placement of smoky, space-greedy industries near the edge of the city (as Area TW was in LC2) is logical. In contrast, production of beads, stone vessels, and inlay involves exotic, beautiful materials and skilled labor to create small numbers of items that reflect high social status or leadership. However, the manufacture of obsidian beads demands knowledge of techniques that overlap with those for producing fine blades. This crossover adds subtle layers to the concept of full-time crafters, who may have specialized in material and techniques, not object types.

\section{Administration and Accounting}

Clay sealings are a powerful proxy for the complexity of urban economies. Increased sophistication in imagery and expansion of sealing practices are associated with widening power and status in the fifth millennium $\mathrm{BC}$ and ultimately with the growth of administrative systems in the fourth millennium BC (Frangipane 2016; 
Pittman 2001). Container sealings suggest mobility of resources, while door sealings may be evidence of corporate or institutional ownership and management of resources or storage.

One reconstruction of LC seal use is based on discard patterns at Arslantepe and proposes that sealings accumulated within central storage facilities due to frequent opening and closing of stationary vessels or rooms. The sealings were curated for administrative and accounting purposes before eventual discard (Ferioli and Fiandra 1994; Fiandra 2009; Frangipane 2012). An alternative reconstruction is based on highly variable sealing imagery at Hacinebi (Stein 2001) and Brak and suggests that sealings reflect the frequent arrival of containers of food, raw materials, and other goods from sources outside each site. After arrival, sealings were removed from their containers and discarded, creating temporally discrete but artistically diverse assemblages.

The LC3 sealings from Brak and Hamoukar are dominated by container sealings and only a few door sealings (Emberling and McDonald 2003; McMahon and Oates 2007; Reichel 2002). At Brak, there are persistent discarded sealings in Area TW across the LC2 through LC3, related to the BTB's oversight of production and the subsequent public role of the feasting building. Excavation of rubbish dumps on the northern and eastern edges of Brak's outer town (Tell Majnuna, Tell T2) recovered hundreds of LC3 sealings. These outer-town discard locations reflect rubbish carried from administrative locations on the core mound. All Brak assemblages comprise mostly container sealings.

At Hamoukar, three LC3 building complexes were excavated at the southeastern corner of the main mound. An assemblage of clay sealings from these was dominated by container sealings but also included door sealings, indicating at least two distinct routines within the administration of resources (Reichel 2002). A small group of LC3 container sealings was recovered from Tell Mozan, but the context is unclear (Kelly-Buccellati 2010). Sealing practices are not exclusive to cities; all LC levels at Tepe Gawra contained container sealings, in storage, temple, and workshop contexts (Rothman 2002).

The visible presentation of ownership represented by sealings grew in importance concurrent with urban growth and associated economic changes from LC2 to LC3. These changes include intensified local trade in basics and extended systems of trade in high-value goods. The questions about the nature of LC power referred to above cascade down to consideration of the economic system. Sealings on goods may be evidence for a robust system of equal exchange, taxation, or coercive power, such as tribute.

The imagery of seals suggests an interest in representing positional power. LC2 seals are dominated by images of animals, snakes, humans drinking from or carrying jars, and hybrid "shaman" figures, many with direct precedents in the late Ubaid. LC3 imagery incorporates more scenes of lions, either lion-goat combats or groups of four or five lions. Images of lion-human combats also first appeared in LC3 and are analogous to the Late Uruk and eventual Neo-Assyrian use of this image to represent the power of individual kings and the concept of kingship (McMahon 2009). Such sealings are potential proxies for LC northern Mesopotamian leadership but are not detailed or specific enough to reference individual leaders. 


\section{Urban Sprawl and Informal Economies}

\section{Sprawl and Low-Density Occupation}

Urban sprawl is a pattern of city growth that involves decentralized, low-density, discontinuous occupation, resulting in high transport costs, limited social integration, and fragmentation of unused land (Galster et al. 2001; Gillham 2002; Irwin and Bockstael 2007; Jaeger et al. 2010). For many scholars, urban sprawl only began with nonfoot transport, such as pack animals, carts, or ships (Glaeser 2011; M. E. Smith 2010), and it is especially associated with the automobile. Urban sprawl in ancient cities has been equated with extramural suburbia and low density with cities in the tropics (M. E. Smith 2010). Both Hamoukar and Brak have attributes of urban sprawl in LC2-3 (see above); low-density use of space is also present.

Calculation of an absolute number of people per hectare to identify low density is problematic, although Fletcher (1995) suggests 10 people per hectare. Instead, relative assessments may be based on variations in artifact densities that are proxies for past use intensity. Based on surface artifact densities, occupation of Hamoukar's Southern Extension was low density, while the main mound was more intensively utilized. In addition, the Southern Extension may not have been entirely contemporary; 31 ha of low mounding at the center represents persistent occupation, while variable density of sherds and obsidian debitage in the remaining c. 275 ha reflect patchy, discontinuous activities. Excavations during 2000-2008 targeted the mounded area and exposed fully sedentary occupation of mudbrick houses, sherd pavements, kilns, and middens (al-Quntar et al. 2011). The patchier pattern outside these low mounds may result from seasonal settlement by nomadic or seminomadic populations (Gibson et al. 2002; Wilkinson 2002). Alternatively, a model of widely separated house clusters that actively maintained social distance may be appropriate (Ur 2010b). The pattern also may derive from houses interspersed with garden agriculture, as reconstructed for some Maya and Aztec cities (Isendahl and Smith 2013). This arrangement does not carry the transport challenges associated with modern urban sprawl, but the scattered residential use has social implications.

Urban sprawl at Tell Brak is more pronounced. As detailed above, Tell Brak grew from c. 55 ha in LC2 to 130 ha in LC3. This sudden growth occurred in an outer town around the core mound. Surface materials suggest that occupation density of the outer town was low but varied, with patches of highly intensive activities. The densest materials are on seven submounds at the edge of the outer town. The density of surface sherds on these submounds is equivalent to that on the core mound and was at first equated with comparable tight domestic occupation (Ur et al. 2007).

The model initially proposed an LC2 city with a dense core and external pockets of population, interpreted as houses of recent immigrants, semi-independent groups, or former core occupants pushed outward by group fissioning. The spaces between submounds and the empty ring between submounds and main mound 
were assumed to be social buffer zones (Ur 2010a). This model is similar to that proposed for Middle Niger clustered cities, with their satellite settlements that may reflect communities of specialists staking out separate occupation zones, helped by the absence of a structuring hierarchy (McIntosh and McIntosh 2003). The pattern further suggests that Brak underwent two changes in LC3: more people inhabited the submounds, and people moved from them inward to fill the intervening vacant area. The area between the core mound and outer ring of submounds unfortunately is disturbed by modern agriculture and ancient exploitation for brick manufacture (Wilkinson et al. 2001), so the nature of space use there is unclear.

During excavations in Brak's outer town in 2006-2011, the submounds proved to be specialized activity areas with little evidence of housing. Empty spaces were potentially related to practical matters such as pollution, rather than maintenance of social distance. The submound of Majnuna, at Brak's northern edge, comprised large-scale rubbish dumping episodes spread across 300-400 years of late LC2LC3 and not occupational deposits as expected. This rubbish was derived from institutional, industrial, and domestic sources within the city center, and it is estimated at $180,000 \mathrm{~m}^{3}$ and $270,000,000 \mathrm{~kg}$. The scale of the deposit and its distance from the core mound suggest it was collected and removed to a distance by common agreement and, perhaps, managed labor (McMahon 2017). Rubbish deposits were observed in earlier soundings in two other submounds (Emberling et al. 1999). At the time, the rubbish was attributed to trench locations on the edges of these mounds, but Majnuna's evidence suggests that these submounds are additional discard zones.

Excavations in Tell T2, at the outer-town's eastern edge, recovered additional large quantities of rubbish but also ephemeral architecture, dozens of pottery kilns, and evidence of other industries, all dating to LC3 (Emberling and McDonald 2001; McMahon 2013; Skuldbøl 2009). Buildings include some single houses and nondomestic structures surrounded by open space. None of the structures was long lasting, and use of space shifted rapidly between different activities, as represented by kilns and a leather-tanning or textile-dyeing pit. We can reconstruct flows of people and goods in and around the outer town: laborers and donkeys making daily rubbish deliveries to Majnuna at the northern edge, a two-way flow of commuter workers, raw materials, and manufactured goods between Tell T2 at the site's east and its core. Finally, both submounds were used for burials during the LC3, drawing episodic visits from across the city's population. The site-edge location of these burials may answer the long-standing question of where the dead were buried in the fourth millennium BC (McMahon and Stone 2013).

The Majnuna and T2 excavations demand an adjustment to the survey-derived model of inward urban growth (Ur 2014). The growth of Brak was centrifugal, not centripetal, sprawl rather than attraction. Site expansion also was largely derived from outward flow of the city's rubbish and industry, rather than houses of newly arrived immigrants or settlers maintaining a distance from the core. However, this flow was potentially a response to increased demands for housing space at the center; population growth was still a strong factor. These outer submounds are analogous to the "leapfrogging" phenomenon in some instances of modern urban sprawl (Gillham 
2002). Leapfrogging contrasts to contiguous urban sprawl through its characteristic bypassing of wooded or agricultural areas. Leapfrog developments are usually attached to the urban core by extended transportation routes and are gradually subsumed into the city as intervening open areas are overtaken. Modern leapfrog developments usually comprise housing, commercial buildings, and/or white-collar business enclaves. The functions of the Brak outer submounds do not overlap with their modern counterparts but may share an origin in inner-city crowding.

\section{Informal Economy}

Urban sprawl at Brak has implications for our model of the urban economy. The famous zone theory of Ernest Burgess (1925), of the first Chicago School of Sociology (1920s-1930s), proposed concentric rings of urban function types radiating from a central business district. The outer ring was reserved for suburban residences of the wealthy. This model was appropriate for many North American cities in the 1920s, and modern urban sprawl in the developed world is still largely suburban. Other cities, however, are inversions; megacity edges in the developing world more often house the poor and disenfranchised than the wealthy. Favelas, banlieues, and shantytowns have limited infrastructure or municipal services and illegal or poorly designed housing. Unemployment is high. Yet peri-urban zones have positive aspects in that they may house small-scale industries and market gardening and thus foster thriving shadow or black-market economies. This "System D" is highly adaptable precisely because its associated infrastructure is limited, and land ownership is mutable; space is easily adjusted to respond rapidly to changing economic demands (Neuwirth 2011). A highly adaptive, improvisational shadow economy may contribute to a city's sustainability by welcoming newly arrived immigrants, supporting flexibly scheduled labor, and allowing occasional profit from windfalls.

This modern solution resonates with past cities. Long-term settlement meant the built environment at the core of Mesopotamian cities was often resistant to change, limited by deep traditions of property ownership. But the edge zone could be a space for innovation and invention, for informal industries and garden agriculture, and for cheap housing as well as expansive villas. The absence of municipal services (sanitation, water provision, rubbish collection) has brought many modern urban edge zones into crisis (Hogrewe et al. 1993). But ancient Mesopotamian cities rarely provided such services even at their centers, and easier access to open space in the edge zone could have simplified individual solutions to these needs. Brak's peri-urban zone housed pottery manufacture, textile or leather processing, and lithic tool production. These industries were small scale and changeable, particularly in contrast to the managed installations on the main mound in Area TW. Pigs were more popular on T2 than on the main mound (Emberling and McDonald 2003; Weber 2014). Pigs are cheap and easy to rear and may have supplemented diets of poor households, such as we associate with laborers. Brak's peri-urban zone thus combines the low density of classic suburbs with the mixed industries and flexible occupation by poor individuals of modern megacities. 


\section{Northern versus Southern Mesopotamian Cities}

\section{Transportation}

Northern Mesopotamian cities cannot be discussed without reference to southern Mesopotamian cities. The Greeks subsumed the whole region under the name Mesopotamia, but the indigenous inhabitants never did so: Sumer and Subartu, or Babylonia and Assyria, were always distinct. The coincidence of rich alluvial soil and the invention of irrigation has been argued as the south's primary advantage (Algaze 2001, 2008). Together these generated high agricultural yields, while rivers and canals provided transport to move those yields to where they could be leveraged for the greatest economic gain. Water transport is still the most efficient and inexpensive way to move cheap bulky goods, such as bricks, pottery, and grain.

However, in the north, the complex topography and hydrology of northern rivers and wadis made canals in this area technically tricky. Some rivers were navigable but not all were perennial. How did northern inhabitants move bricks and grain or disperse pottery from production centers? Donkeys or equid hybrids were domesticated in the fourth millennium BC, but even a donkey train is limited in terms of bulky goods carried. Ox carts are extremely slow, and the wheel may not have been present in this region until the very late fourth millennium BC (Klimscha 2017). This transport limitation meant that northern cities and their hinterlands were potentially more self-sufficient and internally granular in terms of heavy basic goods than were southern cities, where ease of bulk transport meant extended networks. This self-sufficiency in the base economy feeds into aspects of urban scale and form.

\section{Urban Scales and Landscapes}

Uruk (250 ha) in the Late Uruk (Finkbeiner 1991) matched Hamoukar in size but was twice as large as Brak. And most northern cities were much smaller, only 30-50 ha. These scalar differences persisted into the third millennium BC; Early Dynastic al-Hiba at 600 ha had no rival in the north. Even if much of al-Hiba was taken up by industry, gardens, and low-density settlement, it was a massive megacity in Mesopotamian terms. Meanwhile, the north's third and second millennium $\mathrm{BC}$ cities were smaller than their fourth millennium BC predecessors, rarely exceeding 90-100 ha. The scale achieved in the south is probably linked to the ease of canal transportation; canals were not necessary for cities but were necessary for megacities.

Mesopotamian cities can be classified as hybrid, partly planned but mainly organic (M. E. Smith 2003, 2007). For decades, it has appeared that the only urban form unique to northern Mesopotamia was the third millennium BC "Kranzhügel," exemplified by Tell Chuera and Tell Beydar. This form consists of a multiperiod central high mound used as a political and religious citadel, surrounded by a walled circular outer town, with concentric and radial streets and densely packed residential blocks (Meyer 2010). This partial planning is likely due to the presence of leaders 
with significant power to create structure and to displace people. But fourth millennium BC cities had another uniquely northern form, a high, densely occupied core and diffused, largely nonresidential, outer town. For the moment, this can be contrasted to a more homogenous and relatively high-density occupation for contemporary cities in the south. I strongly suspect, however, that variable density will ultimately be proven to exist in southern cities as well, as excavation intensity rebuilds in southern Iraq and sites are intensively surveyed.

Much of Brak's urban landscape was unplanned and bottom-up, in terms of decisions about space use and access routes. But in late LC2, the outward movement of rubbish and industrial activities and the creation of the corona of submounds 200-500 $\mathrm{m}$ from the core settlement captured the intervening space for the city. This movement suggests a possible planned approach to the urban landscape, an act of creation as well as separation. The eventual merging of the submounds with the center may have been intentional or may reflect a breakdown in maintenance of separation. The resulting urban landscape, with its mixture of organic traditions overlain by limited imposed planning, is typical of many successful modern cities (Batty 2013).

\section{City Centers}

The "epicenters" (M. E. Smith 2007) of cities in the south and north also can be contrasted. Central planned zones containing public buildings are widely agreed as vital components of urban settlements that act as proxies for leadership. Southern Mesopotamian leadership clearly built from a strong base in religious power, already established by the middle of the Ubaid (c. 5000 BC). Excavations at Eridu (Safar et al. 1981) confirmed the deep foundations of religious power, and the temple remained the main visible institution in southern Mesopotamia until late in the Early Dynastic period (c. 2500 BC). Many southern Mesopotamian cities have religious buildings at their physical centers. Uruk is the clearest example, but even cities for which the Uruk period occupation is less well known, such as Nippur, have substantial temples as focal points. This monocentric arrangement reminds us of Burgess's central business district (1925), around which the rest of the city revolves.

By contrast, northern Mesopotamian cities may have been polycentric, and northern Mesopotamian temples were never as massive or prominent as those in the south, in any millennium. Tell Brak has its Eye Temple, but it is located at the edge of the main mound, while the contemporary secular institution (BTB) holds a comparable edge position at the north. These two institutions problematize the epicenter concept, and we are still missing other elements of the urban landscape, possibly including additional monumental buildings. The BTB and Eye Temple were located at opposite sides of the core mound and c. $400 \mathrm{~m}$ apart. They may have worked in tandem, since each building sits next to an important entrance into the city. The northern entrance and BTB welcomed travelers from the Taurus Mountains and the Wadi Jaghjagh, while the southern entrance and Eye Temple received visitors coming overland from Assyria or from the south via the Lower Khabur River. Their rough symmetry in placement would have created a distinctive urban skyline from 
both angles. The physical separation and edge locations created a decentralized urban landscape and may reflect a distinctive northern city format.

The area of cities taken up by public buildings also differs between south and north. The Anu and Eanna complexes at Uruk together comprise c. 10 ha, or approximately $4 \%$ of the city. By contrast, the Eye Temple is at most 65 by $26 \mathrm{~m}$; even if the BTB equaled that area and both buildings were in open plazas, these spaces might fill c. 0.5 ha, or less than $1 \%$ of the late LC2 city.

\section{Neighborhoods and Streets}

Density of housing provides a further potential point of contrast between the north and south. I define "neighborhood" at its most basic as a cluster of houses in close proximity, informally accumulated and affording high resident interaction. Excavated urban neighborhoods in the south present a consistent picture: narrow unplanned streets and tightly packed houses with shared exterior walls, e.g., third millennium BC Tell Asmar (Delougaz et al. 1967) or early second millennium BC Ur (Woolley and Mallowan 1976). Our knowledge of neighborhoods of the fourth millennium BC is limited but may be reflected in Uruk colonies such as Habuba Kabira (Strommenger 1980). Northern Mesopotamian neighborhoods have similar contiguous clustered houses, e.g., third millennium BC Tell Taya (Reade 1973) and second millennium BC Tell Munbaqa (Machule 1998) or Tell Bazi (Otto 2006). However, the streets around house clusters in northern cities are broader, often 5-10 $\mathrm{m}$ (or more) wide, in contrast to the 2-3-m-wide streets in the south. The reason may be economic or social. Narrow streets can be navigated by people, donkeys, and small carts but are not well adapted for flocks of sheep and goats, which could easily transit the wider streets of the north. Because of the crucial importance of pastoralism in the economy of northern cities, domestic animals were integrated within settlements, while those in the south were stabled at a distance. In addition, reliance on animal transport in the north, not river transport, could have affected street width. Streets also have a huge impact on daily life, privacy, communication, and transactions. The wider streets of the north may reflect a greater need for social distance among neighborhood inhabitants or conversely may have supported large outdoor gatherings. More excavation of fourth millennium BC neighborhoods in the south and north, and in high-and low-density areas within cities, is needed to explore this issue further.

\section{Sustainability and Conflict}

Given the political collapses and abrupt climatic events in Mesopotamian history, system resilience, or its lack, is a frequent point of discussion (e.g., Adams 1978; Redman and Kinzig 2003; Riehl et al. 2014; Ur 2015; Wilkinson 1997). The concept of urban sustainability is similar to that of systemic resilience but scaled down to settlement level. A distinction must be drawn between modern city sustainability that focusses on livability and ecological matters (e.g., renewable energy, recycling) 
and ancient city sustainability that has settlement longevity at its core (Isendahl and Smith 2013; M. E. Smith 2010). Ancient urban sustainability weighs the disadvantages to city-dwelling individuals against the advantages to the larger group. It moves away from the idea of institutional stability to focus on social solutions to man-made challenges and continuity through conflict.

\section{Achieving Net Immigration}

The rapidity of Brak's LC3 growth implies that natural population increase was not its sole cause, and the regional survey suggests local immigration. Traditional models propose economic efficiency, trade goods access, or safety as incentives for urban population agglomeration. But an approach allowing for individual agency shifts these to choices: employment opportunities rather than efficiency, and the search for social connections rather than safety. Temple institutions may draw people close with soft power via the attraction of religious feeling. But deep examination of population numbers from ancient and premodern cities suggests that simple immigration from an adjacent hinterland would barely have been sufficient to overcome urban mortality rates (Algaze 2018; Davis 1965; de Ligt 2013). Eventually, the rural well of population would run dry. Expanding cities in southern and northern Mesopotamia thus may have welcomed newly settled nomadic pastoralists (Adams and Nissen 1972; Johnson 1988-1989). And the possibility exists that more distant populations were engaged. Comparison of LC4-5 settlement patterns for southern Mesopotamia and the Iraqi Jezirah reveals that the Jezirah population declined at the same time that the population of the area around Uruk grew, after c. 3500 BC (Kouchoukos and Wilkinson 2007). City contraction in the north thus may have enabled the urban expansion of Uruk (Algaze 2008, 2018). But the question of the population source for growing LC2-3 cities of northern Mesopotamia is unanswered; southern populations slowly increased in the Early and Middle Uruk, so it is not a situation of bimodal migration between south and north. Potential population sources for northern LC2-3 cities are eastern Anatolia and Transcaucasia, but more work is needed to reconcile settlement trends among these regions.

The inverse of immigration-emigration-is rarely considered in assessment of city dynamics, and then only in relation to state collapse. Algaze (2018) argues for constant immigration to maintain cities, but his only scenario for city inhabitants' departure is their death. Brak, Hamoukar, and other northern Mesopotamian cities contracted significantly in LC4. Emigration is part of the explanation, and the chronology dovetails with expansion of population in the south. Emigration can be explained as flight from oppression by leaders or from the stress of urban living. The evidence for informal economies and violence suggests that urban opportunities for employment and aspects of safety were illusory. But we may be underestimating the mobility-local and regional-of the past inhabitants of Mesopotamia (M. L. Smith 2014), particularly when cities were new and tenuously established. 


\section{City Living}

Modern urban sustainability challenges include garbage removal, sanitation, and clean water access, and these challenges have persisted from the earliest Mesopotamian cities (McMahon 2015). These sustainability challenges to settlements also affect the individual experience of city living, and in Mesopotamia, they were not mitigated by municipal services provided by leaders or institutions. Population agglomeration added time and effort to daily tasks. For example, a villager's solo trip to a well became a city dweller's crowded wait for access to an optimal riverbank spot. Water requirements for large families demanded several trips per day and huge time and energy investments. The search for household fuel required everlonger trips to reach unexploited stands of trees or more time invested in dung-cake making. Further, the efficient clustering of pottery production elevated that industry's demands for fuel. Removal of refuse and waste was also a mounting challenge, as ever larger populations generated more trash, and empty or underused spaces within the city were filled. The accumulation of trash may be linked to the increased representation of the vulture, a scavenging species, on LC3 sealings at Brak (McMahon 2016). The submound of Majnuna became a location for the discard of Brak's rubbish, a 400-m walk that at least might have offered the supplemental opportunity for private defecation. But the compensations for the time and energy demanded of city dwellers seem poor. Population concentration created greater opportunities for social engagement, but did that compensate for poor sanitation and high mortality? Did positive aspects of community and employment overcome the grinding negatives of crowding and over-used resources?

At least Mesopotamian cities were "walking cities," compact and small enough that animal transport was not needed. But city growth was potentially associated with the formalization of public access and customary traffic routes. There is a rich Sumerian and Akkadian vocabulary for streets in later periods in Mesopotamia. Street terms have been linked with differences in scale, such as broad versus narrow, and with degrees of connectivity, e.g., integrated versus blind alleys (Steinert 2011). Although it is risky to stretch second or first millennium BC analogies into prehistory, the three main distinctions of blind alley, intrasettlement street, and intercity road may have first developed in the fourth millennium BC, which saw infilling of open spaces and increasing ownership of the landscape inside and outside settlements. The first steps from walking to work to commuting may have been taken, as the closing urban landscape restricted its inhabitants' abilities to wander (see also Yoffee 2015).

\section{Warfare and Violence}

Archaeologists and historians often ascribe a near-permanent state of conflict to southern Mesopotamia in the Early Dynastic third millennium BC, based on artistic representations and royal inscriptions (Hamblin 2006; Nissen 1988). But this ascription ignores the political nature of such texts and artworks and downplays the 
lack of archaeological traces of conflict. By contrast, there has been a peculiar reluctance to address the possibility of conflict in prehistory. Yet excavations in northern Mesopotamia have recovered evidence of violent conflict associated with urbanism. Tell Majnuna at Brak was the site of three LC3 mass graves of mainly young adults (McMahon 2014; McMahon et al. 2011). Excavations at Hamoukar recovered hundreds of sling bullets, buildings destroyed by fire, and single graves (Reichel 2009). Tepe Gawra was destroyed by fire at least twice during the LC, clay and stone ballistas were common in several LC levels, and there are skeletons with evidence of violent death from an LC1 level (Butterlin 2009; Rothman 2002, 2009).

The mass graves at Brak are contemporary with the site's rapid growth in LC3. Three separate violent conflicts resulted in the death of up to several hundred individuals each time. Animal bones incorporated with the final layer of the main mass grave exhibit the feasting signature identified for the roughly contemporary feasting building (Weber 2014) and suggest a celebration of victory. The graves were covered by a heap of rubbish that became a permanent marker connecting that part of the urban landscape with conflict. The size of Brak makes it unlikely that it would be a target of external attack, and there were no sites of equivalent power within striking distance. Instead it is probable that the graves resulted from civil war generated by internal social stresses associated with urbanism. Expansion of Brak's institutions may have been accompanied by unsustainable increases in tax or tribute obligations that triggered resistance and violent suppression. Alternatively, growth in population, with associated crowding, demands on resources, and disparities in status and wealth may have incited civil unrest.

By contrast, the slightly later evidence of conflict from Hamoukar (c. 3500 BC) is associated with southern Uruk attackers. This reconstruction presents an alternative model for the Uruk expansion, not a colonial imposition or relationship of equals but an adversarial and violent interaction. The Tepe Gawra evidence is more ambiguous-fire may result from accidents as well as violence, and the site's smaller scale allows for internal or external conflict.

The evidence for violent conflict might seem to suggest that city growth came about from the need for safety. None of these sites is in an inherently defensible location and they lack city walls, but there may have been safety afforded by population numbers and settlement size, especially when set within an emptied landscape in which approaching attackers could be clearly seen across fields. Such a scenario has been proposed for population movement in southern Iraq in the Jemdet Nasr-Early Dynastic I (Adams and Nissen 1972) and for the US Southwest in c. $1150 \mathrm{AD}$, where population aggregation and "no man's lands" were responses to an increase in warfare (Lambert 2002; LeBlanc 1999). But the only possible enemy in the Brak scenario came from within and after the city was already growing, while the enemies in the Hamoukar case were foreign invaders. Population aggregation can cause conflict as well as provide protection. The Brak and Hamoukar evidence should not be taken as indication that all urban growth and intercultural contacts in the region were violent. As Lawrence and Wilkinson state (2015), there were no disruptions in settlement patterns to suggest widespread and persistent conflict or power shifts. These episodes instead express the short-term social stresses that accompanied urbanism. 


\section{Conclusion}

Since the 1990s, the accumulation of data reflecting social and economic complexity and site scale in the fourth millennium BC has introduced northern Mesopotamia's unique contribution to global trends in urbanism. Research here compels recognition of the diverse forms of Mesopotamian cities and reinforces the social experimentation in the earliest cities. Despite the rapid growth and success of northern Mesopotamian cities, urban living brought conflict and disadvantages. However, large areas of northern Mesopotamia, even within the regions of the Upper Khabur and Iraqi Jezira, remained unurbanized, presenting potential safety valves and alternatives.

Northern cities in the fourth millennium BC are characterized by variable density and multiple epicenters of power. The nature of urban power in northern Mesopotamia resists categorization. Extensive agriculture, internal conflict, and the lack of institution-supplied "public goods," such as equal access to resources or provision of urban infrastructure, suggest autocratic rule (Blanton 2010; Blanton and Fargher 2008 , 2011). But the rapid growth of population and mass production responding to market demands may reflect collective action.

Unanswerable questions about northern Mesopotamian urbanism remain. Were social networks provided by ancient cities adequate to prevent unemployment and poverty? What tied urban dwellers together: religion, collective action, or coercion? Did the close relationship between cities and their hinterlands provide a safety valve that inhibited cities from erupting into frequent conflict? The challenges and success of northern Mesopotamian cities inform a crucial chapter in the history of urbanism.

Open Access This article is distributed under the terms of the Creative Commons Attribution 4.0 International License (http://creativecommons.org/licenses/by/4.0/), which permits unrestricted use, distribution, and reproduction in any medium, provided you give appropriate credit to the original author(s) and the source, provide a link to the Creative Commons license, and indicate if changes were made.

\section{References Cited}

Abu Jayyab, A. K. (2012). A ceramic chronology from Tell Hamoukar's southern extension. In Marro, C. (ed.), After the Ubaid: Interpreting Change from the Caucasus to Mesopotamia at the Dawn of Urban Civilization (4500-3500 BC), De Boccard, Paris, pp. 87-123.

Adams, R. McC. (1965). Land Behind Baghdad: A History of Settlement on the Diyala Plains, University of Chicago Press, Chicago.

Adams, R. McC. (1978). Strategies of maximization, stability, and resilience in Mesopotamian society, settlement, and agriculture. Proceedings of the American Philosophical Society 122: 329-335.

Adams, R. McC. (1981). Heartland of Cities. Surveys of Ancient Settlement and Land Use on the Central Floodplain of the Euphrates, University of Chicago Press, Chicago.

Adams, R. McC. (2012). Ancient Mesopotamian urbanism and blurred disciplinary boundaries. Annual Review of Anthropology 41: 1-20.

Adams, R. McC., and Nissen, H. J. (1972). The Uruk Countryside: The Natural Setting of Urban Societies, University of Chicago Press, Chicago.

Akkermans, P. (1988). An updated chronology for the Northern Ubaid and Late Chalcolithic periods in Syria: New evidence from Tell Hammam et-Turkman. Iraq 50: 109-145. 
Algaze, G. (1993). The Uruk World System: The Dynamics of Expansion of Early Mesopotamian Civilization, University of Chicago Press, Chicago.

Algaze, G. (2001). Initial social complexity in southwestern Asia: The Mesopotamian advantage. Current Anthropology 42: 199-233.

Algaze, G. (2008). Ancient Mesopotamia at the Dawn of Civilization: The Evolution of the Urban Landscape, University of Chicago Press, Chicago.

Algaze, G. (2018) Entropic cities: The paradox of urbanism in ancient Mesopotamia. Current Anthropology 59: 23-54.

Al-Quntar, S., and Abu Jayyab, A. K. (2014). The political economy of the Upper Khabur in the Late Chalcolithic 1-2: Ceramic mass-production, standardization and specialization. In McMahon, A., and Crawford, H. (eds.), Preludes to Urbanism: The Late Chalcolithic of Mesopotamia, McDonald Institute for Archaeological Research, Cambridge, pp. 89-108.

Al-Quntar, S., Khalidi, L., and Ur, J. (2011). Proto-urbanism in the late 5th millennium BC: Survey and excavations at Khirbat al-Fakhar (Hamoukar), northeast Syria. Paléorient 37(2): 151-75.

Al-Soof, B. 1969. Excavations at Tell Qalinj Agha (Erbil), summer 1968. Sumer 25: 3-42.

Al-Soof, B., and El-Siwwani S. (1967). Tell Qalinj Agha. Sumer 23: 69-75.

Altaweel, M. (2015). Settlement dynamics and hierarchy from agent decision-making: A method derived from entropy maximization. Journal of Archaeological Method and Theory 22: 1122-1150.

Altaweel, M., Marsh, A., Mühl, S., Nieuwenhuyse, O., Radner, K., Rasheed, K., and Saber, S. (2012). New Investigations in the environment, history and archaeology of the Iraqi Hilly Flanks: Shahrizor Survey Project 2009-2011. Iraq 74: 1-35.

Bagg, A. (2000). Irrigation in northern Mesopotamia: Water for the Assyrian capitals (12th-7th centuries BC). Irrigation and Drainage Systems 14: 301-324.

Baldi, J. (2012). Tell Feres al-Sharqi in the LC 1-2 period: Serial production and regionalization of ceramic traditions: A perspective from a small site. In Marro, C. (ed.), After the Ubaid: Interpreting Change from the Caucasus to Mesopotamia at the Dawn of Urban Civilization (4500-3500 $B C)$, De Boccard, Paris, pp. 129-162.

Ball, W. (1990). Tell al-Hawa and the development of urbanization in the Jazira. Al-Rafidan 11: 1-28.

Ball, W., Tucker, D., and Wilkinson, T. J. (1989). The Tell al-Hawa Project: Archaeological investigations in the north Jazira 1986-87. Iraq 51: 1-66.

Batty, M. (2013). The New Science of Cities, MIT Press, Cambridge, MA.

Bernbeck. R. (1999). Landflucht und Ethnizität im alten Mesopotamien. In Kühne, K., Bernbeck, R., and Bartl, K. (eds.), Fluchtpunkt Uruk, Archäeologische Einheit aus methodischer Vielfalt, Schriften für Hans Jörg Nissen, Verlag Marie Leidorf, Rahden, pp. 296-310.

Bettencourt, L., and West, G. (2010). A unified theory of urban living. Nature 467: 912-913.

Beuger, C. (2016). Short notes on Chalcolithic pottery research: The pottery sequences of Tell Nader (Erbil) and Ashur (Qal'at Shergat). In Kopanias, K., and MacGinnis, J. (eds.), The Archaeology of the Kurdistan Region of Iraq and Adjacent Regions, Archaeopress, Oxford, pp. 19-27.

Beyer, D. (1998). Évolution de l'espace bâti sur un site de la vallée du Khabur au IVe millénaire: Les fouilles de Mashnaqa. In Fortin, M., and Aurenche, O. (eds.), Espace naturel, espace habité en Syrie du Nord (Xe-IIe millénaires av. J-C.), Canadian Society for Mesopotamian Studies, Toronto, and Maison de l'Orient, Lyon, pp. 139-148.

Blanton, R. (2010). Collective action and adaptive socioecological cycles in premodern states. CrossCultural Research 44: 41-59.

Blanton, R., and Fargher, L. (2008). Collective Action in the Formation of Pre-Modern States, Springer, New York.

Blanton, R., and Fargher, L. (2011). The collective logic of pre-modern cities. World Archaeology 43: $505-522$.

Brustolon, A., and Rova, E. (2007). The Late Chalcolithic period in the Tell Leilan region: A report on the ceramic material of the 1995 survey. Kaskal 4: 1-42.

Burgess, E. (1925). The growth of the city: An introduction to a research project. In Park, R., Burgess, E., and McKenzie R. (eds.), The City, University of Chicago Press, Chicago, pp. 47-62.

Butterlin, P. (2009). Tepe Gawra et le monde proto-urbain de Mésopotamie. In Butterlin, P. (ed.), À propos de Tepe Gawra: Le monde proto-urbain de Mésopotamie, Subartu 23, Brepols, Turnhout, pp. $1-14$.

Casana, J. (2013). Radial route systems and agro-pastoral strategies in the Fertile Crescent: New discoveries from western Syria and southwestern Iran. Journal of Anthropological Archaeology 32: 257-273. 
Cegielski, W., and Rogers, J. D. (2016) Rethinking the role of agent-based modeling in archaeology. Journal of Anthropological Archaeology 41: 283-298.

Charles, M., Pessin, H., and Hald, M. M. (2010). Tolerating change at Late Chalcolithic Tell Brak: Responses of an early urban society to an uncertain climate. Environmental Archaeology 15: 183-198.

Childe, V. G. (1950). The urban revolution. The Town Planning Review 21: 3-17.

Cowgill, G. (2004). Origins and development of urbanism: Archaeological perspectives. Annual Review of Anthropology 33: 525-549.

Creekmore, A. (2007). The Upper Tigris Archaeological Research Project (UTARP): A summary and synthesis of the Late Chalcolithic and Early Bronze Age remains from the first three seasons at Kenan Tepe. Anatolica 33: 75-128.

Crüsemann, N. (ed.) (2013). Uruk: 5000 Jahre Megacity, Michael Imhof Verlag, Petersburg.

Davis, K. (1965). The urbanization of the human population. Scientific American 213: 40-53.

Deckers, K. (2011). Riverine development in the Tell Hamidi surroundings. In Deckers, K. (ed.), Holocene Landscapes through Time in the Fertile Crescent, Subartu 27, Brepols, Turnhout, pp. 85-96.

Deckers, K. (2016). Oak charcoal from northeastern Syria as proxy for vegetation, land use and climate in the second half of the Holocene. Review of Palaeobotany and Palynology 230: 22-36.

Deckers, K., and Riehl, S. (2007). Fluvial environmental contexts for archaeological sites in the Upper Khabur basin (northeastern Syria). Quaternary Research 67: 337-348.

de Gruchy, M. (2016). Beyond replication: The quantification of route models in the north Jazira, Iraq. Journal of Archaeological Method and Theory 23: 427-447.

de Ligt, L. (2013). Population and migration. In Clark, P. (ed.), The Oxford Handbook of Cities in World History, Oxford University Press, Oxford, pp. 147-163.

Delougaz, P., Hill, H., and Lloyd, S. (1967). Private Houses and Graves in the Diyala Region, Oriental Institute Publication 88, Oriental Institute, Chicago.

Dyball, R., and Newell, B. (2015). Understanding Human Ecology: A Systems Approach to Sustainability, Routledge, Oxford.

Eidem, J., and Warburton, D. (1996). In the land of Nagar: A survey around Tell Brak. Iraq 58: 51-64.

Emberling, G. (2002). Political control in an early state: The Eye Temple and the Uruk expansion in northern Mesopotamia. In al-Gailani Werr, L., Curtis, J., Martin, H. McMahon, A., Oates, J., and Reade, J. (eds.), Of Pots and Plans, Papers on the Archaeology and History of Mesopotamia and Syria Presented to David Oates in Honour of his 75th birthday, Nabu Publications, London, pp. 82-90.

Emberling, G. (2003). Urban social transformations and the problem of the 'first city': New research from Mesopotamia. In Smith, M. L. (ed.), The Social Construction of Ancient Cities, Smithsonian Institution Press, Washington, DC, pp. 254-268.

Emberling, G. (2015). Structures of authority: Feasting and political practice in the earliest Mesopotamian states. In Emberling, G. (ed.), Social Theory in Archaeology and Ancient History, Cambridge University Press, Cambridge, pp. 34-59.

Emberling, G., Cheng, J., Larsen, T., Pittman, H., Skuldboel, T., Weber, J., and Wright, H. (1999). Excavations at Tell Brak 1998, preliminary report. Iraq 61: 1-41.

Emberling, G., and McDonald, H. (2001). Excavations at Tell Brak 2000, preliminary report. Iraq 63: 21-54.

Emberling, G., and McDonald, H. (2003). Excavations at Tell Brak 2001-2002, preliminary report. Iraq 65: $1-75$.

Evans, D., Pottier, C., Fletcher, R., Hensley, S., Tapley, I., Milne, A., and Barbetti, M. (2007). A comprehensive archaeological map of the world's largest preindustrial settlement complex at Angkor, Cambodia. Proceedings of the National Academy of Sciences USA 104: 14277-14282.

Falconer, S. (1994). Village economy and society in the Jordan Valley: A study of Bronze Age rural complexity. In Schwartz, G., and Falconer, S. (eds.), Archaeological Views from the Countryside, Village Communities in Early Complex Societies, Smithsonian Institution Press, Washington, DC, pp. 121-142.

Ferioli, P., and Fiandra, E. (1994). Archival techniques and methods at Arslantepe. In Ferioli, P., Fiandra, E., Fissore, G., and Frangipane, M. (eds.), Archives Before Writing, Scriptorium, Torino, pp. $149-161$.

Fiandra, E. (2009). Les cretulae à travers le temps: Gawra comme étape dans l'evolution des systèmes adminstratifs. In Butterlin, P. (ed.), À propos de Tepe Gawra: Le monde proto-urbain de Mésopotamie, Subartu 23, Brepols, Turnhout, pp. 81-91. 
Finkbeiner, U. (1991). Uruk: Kampagne 35-37, 1982-84: Die archäologische Oberflachen-Untersuchung, Philipp von Zabern, Maiz am Rhein.

Finley, M. (1977). The ancient city: From Fustel de Coulanges to Max Weber and beyond. Comparative Studies in Society and History 19: 305-327.

Fletcher, R. (1995). The Limits of Settlement Growth: A Theoretical Outline. Cambridge University Press, Cambridge.

Forest, J. D., and Vallet, R. (2008). Tell Feres al Sharqi: Un site Late Chalcolithic dans le Khabur (Syrie). Paléorient 34(1): 191-198.

Frangipane, M. (1994). The record function of clay sealings in early administrative systems as seen from Arslantepe-Malatya. In Ferioli, P., Fiandra, E., Fissore, G., and Frangipane, M. (eds.), Archives Before Writing, Scriptorium, Torino, pp. 125-137.

Frangipane, M. (2001). Centralization processes in Greater Mesopotamia: Uruk 'expansion' as the climax of systemic interactions among areas of the Greater Mesopotamian region. In Rothman, M. (ed.), Uruk Mesopotamia and Its Neighbors. Cross-Cultural Interactions in the Era of State Formation, School of American Research Press, Santa Fe, NM, pp. 307-347.

Frangipane, M. (2009). Non-urban hierarchical patterns of territorial and political organisation in northern regions of Greater Mesopotamia: Tepe Gawra and Arslantepe. In Butterlin, P. (ed.), À propos de Tepe Gawra: Le monde proto-urbain de Mésopotamie, Subartu 23, Brepols, Turnhout, pp. 135-148.

Frangipane, M. (2012). Fourth millennium Arslantepe: The development of a centralised society without urbanism. Origini 34: 19-40.

Frangipane, M. (2016). The origins of administrative practices and their developments in Greater Mesopotamia. The evidence from Arslantepe. Archéo-Nil 26: 9-32.

Frangipane, M. (2018). Different trajectories in state formation in Greater Mesopotamia: A view from Arslantepe (Turkey). Journal of Archaeological Research 26: 3-63.

Galster, G., Hanson, R., Ratcliffe, M., Wolman, H., Coleman, S., and Freihage, J. (2001). Wrestling sprawl to the ground: Defining and measuring an elusive concept. Housing Policy Debate 12: 681-717.

Gavagnin, K., Iamoni, M., and Palermo, R. (2016). The Land of Nineveh Archaeological Project: The ceramic repertoire from the Early Pottery Neolithic to the Sasanian period. Bulletin of the American Schools of Oriental Research 375: 119-169.

Gibson M. (1972). The City and Area of Kish, Field Research Projects, Miami.

Gibson, M., Al-Azm, A., Reichel, C., Quntar, S., Franke, J., Khalidi, L., et al. (2002). Hamoukar: A summary of three seasons of excavation. Akkadica 123: 11-34.

Gillham, O. (2002). The Limitless City: A Primer on the Urban Sprawl Debate, Island Press, Washington, DC.

Glaeser, E. L. (2011). Triumph of the City: How Our Greatest Invention Makes Us Richer, Smarter, Greener, Healthier and Happier, Penguin Press, New York.

Gut, R. (1995). Das Prähistorische Ninive. Zur relative Chronologie der frühen Perioden Nordmesopotamiens, von Zabern, Mainz am Rhein.

Hald, M. M. (2008). A Thousand Years of Farming: Late Chalcolithic Agricultural Practices at Tell Brak in Northern Mesopotamia, Archaeopress, Oxford.

Hald, M. M., and Charles, M. (2008). Storage of crops during the fourth and third millennia BC at the settlement mound of Tell Brak, northeast Syria. Vegetation History and Archaeobotany 17 (Suppl. 1): $35-41$.

Hall. P. (1998). Cities in Civilization, Pantheon Books, New York.

Hamblin, W. J. (2006). Warfare in the Ancient Near East to 1600 BC: Holy Warriors at the Dawn of History, Routledge, London.

Hansen, M. (2004). The Hellenic polis. In Hansen, M. (ed.), A Comparative Study of Thirty City-State Cultures, Royal Danish Academy of Sciences and Letters, Copenhagen, pp. 141-187.

Helmer, D., Gourichon, L., and Vila, E. (2007) The development of the exploitation of products from Capra and Ovis (meat, milk and fleece) from the PPNB to the Early Bronze in the northern Near East (8700 to 2000 BC cal.). Archaeozoologica 42: 41-69.

Helwing, B. (2000). Regional variation in the composition of Late Chalcolithic pottery assemblages. In Marro, C., and Hauptman, H. (eds.), Chronologies des pays du Caucase et de l'Euphrate aux IVeIIIe millenaires, Institut Français d'Études Anatoliennes, Istanbul, pp. 145-164.

Hietala, M., and Clark, P. (2013). Creative cities. In Clark, P. (ed.), The Oxford Handbook of Cities in World History, Oxford University Press, Oxford, pp. 720-735. 
Hijara, I. (1973). Excavations at Tell Qalinj Agha (Erbil), fourth season 1970. Sumer 29: 13-35.

Hogrewe, W., Joyce, S., and Perez, E. (1993). The Unique Challenges of Improving Peri-Urban Sanitation, Water and Sanitation for Health Technical Report 86, U.S. Agency for International Development, Washington, DC.

Hole. F. (2001). A radiocarbon chronology for the Middle Khabur, Syria. Iraq 63: 67-98.

Hritz, C. (2014). Contributions of GIS and satellite-based remote sensing to landscape archaeology in the Middle East. Journal of Archaeological Research 22: 229-276.

Iamoni, M. (2016). The Land of Nineveh Archaeological Project in Iraqi Kurdistan: The prehistory and protohistory of the Upper Tigris rediscovered. In Kopanias, K., and MacGinnis, J. (eds.), The Archaeology of the Kurdistan Region of Iraq and Adjacent Regions, Archaeopress, Oxford, pp. $125-134$.

Irwin, E., and Bockstael, N. (2007). The evolution of urban sprawl: Evidence of spatial heterogeneity and increasing land fragmentation. Proceedings of the National Academy of Sciences USA 104: 20672-20677.

Isendahl, C., and Smith, M. E. (2013). Sustainable agrarian urbanism: The low-density cities of the Mayas and Aztecs. Cities 31: 132-143.

Jacobs, J. (1969). The Economy of Cities, Random House, New York.

Jaeger, J., Bertiller, R., Schwick, C., and Keinast, F. (2010). Suitability criteria for measures of urban sprawl. Ecological Indicators 10: 397-406.

Janusek, J., and Blom, D. (2006). Identifying Tiwanaku urban populations: Style, identity, and ceremony in Andean cities. In Storey, G. (ed.), Urbanism in the Preindustrial World: Cross-Cultural Approaches, University of Alabama Press, Tuscaloosa, pp. 233-251.

Jas, R. (2000). Land tenure in northern Mesopotamia. In Jas, R. (ed.), Rainfall and Agriculture in Northern Mesopotamia, Nederlands Historisch-Archaeologisch Instituut te Istanbul, Leiden, pp. 247-263.

Johnson, G. (1988-1989). Late Uruk in Greater Mesopotamia: Expansion or collapse. Origini 14: $595-611$.

Kelly-Buccellati, M. (2010). Mozan/Urkesh in the Late Chalcolithic period. In Becker, J., Hempelmann, R., and Rehm, E. (eds.), Kulturlandschaft Syrien, Zentrum und Peripherie. Festschrift für JanWaalke Meyer, Alter Orient und Altes Testament 371, Ugarit Verlag, Münster, pp. 261-290.

Kennett, D., and Kennett, J. (2006). Early state formation in southern Mesopotamia: Sea levels, shorelines, and climate change. Journal of Island and Coastal Archaeology 1: 67-99.

Kepinski, C. (2009). Grai Resh et la haute-Mésopotamie de 4200 à 3600 av. J.-C.: Des contacts lointains aux stratégies territoriales. In Butterlin, P. (ed.), A propos de Tepe Gawra: Le monde proto-urbain de Mésopotamie, Subartu 23, Brepols, Turnhout, pp. 121-134.

Kepinski, C. (2011). New evidence from Grai Resh, northern Iraq, the 2001 and 2002 seasons: A preUruk expansion site from the Late Chalcolithic period. Zeitschrift für Orient-Archäologie 4: 46-85.

Khalidi, L. (2014). Fifth-millennium BC obsidian production and consumption in Area TW, Tell Brak. In McMahon, A., and Crawford, H. (eds.), Preludes to Urbanism: The Late Chalcolithic of Mesopotamia, McDonald Institute for Archaeological Research, Cambridge, pp. 69-87.

Khalidi, L., Gratuze, B., and Boucetta, S. (2009). Provenance of obsidian excavated from Late Chalcolithic levels at the sites of Tell Hamoukar and Tell Brak, Syria. Archaeometry 51: 879-893.

Klimscha, F. (2017). Transforming technical know-how in time and space: Using the Digital Atlas of Innovations to understand the innovation process of animal traction and the wheel. eTopoi Journal for Ancient Studies 6: 16-63.

Kolinski, R. (2016). Insights into the settlement history of Iraqi Kurdistan from the Upper Greater Zab Archaeological Reconnaissance Project. In Kopanias, K., and MacGinnis, J. (eds.), The Archaeology of the Kurdistan Region of Iraq and Adjacent Regions, Archaeopress, Oxford, pp. 163-172.

Kopanias, K., Beuger, C., Carter, T., Fox, S., Hadjikoumis, A., Kourtessi-Philippakis, G., Livarda, A., and MacGinnis, J. (2013). The Tell Nader and Tell Baqrta Project in the Kurdistan region of Iraq: Preliminary report of the 2011 season. Subartu 6-7: 23-57.

Kopanias, K., Beuger, C., MacGinnis, J., and Ur, J. (2016). The Tell Baqrta Project in the Kurdistan region of Iraq. In MacGinnis, J., Wicke, D., and Greenfield, T. (eds.), The Provincial Archaeology of the Assyrian Empire, McDonald Institute for Archaeological Research, Cambridge, pp. 117-128.

Kouchoukos, N., and Wilkinson, T. (2007). Landscape archaeology in Mesopotamia: Past, present, and future. In Stone, E. (ed.), Settlement and Society, Essays Dedicated to Robert McCormick Adams, Cotsen Institute of Archaeology, University of California, Los Angeles, pp. 1-18. 
Lambert, P. 2002. The archaeology of war: A North American perspective. Journal of Archaeological Research 10: 207-241.

Landry, C. (2000). The Creative City: A Toolkit for Urban Innovators, Earthscan, London.

Lawrence, D., Philip, G., Wilkinson, K., Buylaert, J., Murray, A., Thompson, W., and Wilkinson, T.J. (2017). Regional power and local ecologies: Accumulated population trends and human impacts in the northern Fertile Crescent. Quaternary International 437: 60-81.

Lawrence, D., and Wilkinson, T. J. (2015). Hubs and upstarts: Pathways to urbanism in the northern Fertile Crescent. Antiquity 89: 328-344.

LeBlanc, S. (1999). Prehistoric Warfare in the American Southwest, University of Utah Press, Salt Lake City.

Liverani, M. (2006). Uruk, The World's First City, Equinox, London.

Lyonnet, B. (1996). La prospection archéologique de la partie occidentale du Haut-Khabur (Syrie du nord-est): Méthodes, résultats et questions autour de l'occupation aux IIIe et IIe millénaires av. n.E. In Durand, J.-M. (ed.), Mari, Ébla et les Hourites, dix annes de travaux, Amurru 1, Etudes et Recherche sur les Civilisations, Paris, pp. 363-376.

Lyonnet, B. (2000). Prospection archéologique du Haut-Khabur Occidental (Syrie du N.E.), Bibliothèque Archéologique et Historique, Beirut.

Lyonnet, B. (2009). Périphérie de la Mésopotamie à la période d'Uruk (IVe millenaire): Le cas des regions du Caucase. In Durand, J., and Jacquet, A. (eds.), Centre et péripherie; Approches nouvelles des Orientalistes, Institut du Proche-Orient Ancien, Paris, pp. 1-15.

Machule, D. (1998). 1969-1994: Ekalte (Tall Munbaqa), Eine bronzezeitliche Stadt in Syrien. In Wilhelm, G. (ed.), Zwischen Tigris und Nil. 100 Jahre Ausgrabungen der Deutschen Orient-Gesellschaft in Vorderasien und Ägypten, von Zabern, Mainz, pp. 115-125.

Mallowan, M. (1936). Excavations at Tell Chagar Bazar and an archaeological survey of the Habur region, 2nd campaign, 1936. Iraq 4: 91-177.

Mallowan, M. (1947). Excavations at Brak and Chagar Bazar. Iraq 9: 1-259.

Marro, C. (2010). Where did Late Chalcolithic Chaff-Faced Ware originate? Cultural dynamics in Anatolia and Transcaucasia at the dawn of urban civilization (ca. 4500-3500 BC). Paléorient 36(2): 35-55.

Marro, C., and Hauptmann, H. (eds.) (2000). Chronologies des pays du Caucase et de l'Euphrate aux IVe-IIIe millénaires, Varia Anatolica 11, De Boccard, Paris.

Matthews, R. (2003). Traces of early complexity: Late fifth to early fourth-millennia investigations: The Early Northern Uruk period. In Matthews, R. (ed.), Excavations at Tell Brak, Volume 4: Exploring an Upper Mesopotamian Regional Centre, 1994-1996, McDonald Institute for Archaeological Research, Cambridge, pp. 25-52.

Mattingly, D., Stone, D., Stirling, L., and Ben Lazreg, N. (2001). Leptiminus (Tunisia), A 'producer city'? In Mattingly, D., and Salmon, J. (eds.), Economies Beyond Agriculture in the Classical World, Routledge, Oxford, pp. 66-89.

McCorriston, J. (1997). The fiber revolution: Textile extensification, alienation, and social stratification in ancient Mesopotamia. Current Anthropology 38: 517-549.

McIntosh, R., and McIntosh, S. (2003). Early urban configurations on the Middle Niger, clustered cities and landscapes of power. In Smith, M. L. (ed.), The Social Construction of Ancient Cities, Smithsonian Books, Washington, DC, pp. 103-120.

McMahon, A. (2009). The lion, the king and the cage: Late Chalcolithic iconography and ideology in northern Mesopotamia. Iraq 71: 115-124.

McMahon, A. (2013). Tell Brak, early northern Mesopotamian urbanism, economic complexity and social stress, fifth-fourth millennia BC. In Bonatz, D., and Martin, L. (eds.), 100 Jahre Archäeologische Feldforschungen in Nordost-Syrien-Eine Bilanz, Harrassowitz, Weisbaden, pp. 67-80.

McMahon A. (2014). State warfare and pre-state violent conflict: Battle's aftermath at Late Chalcolithic Tell Brak. In McMahon, A., and Crawford, H. (eds.), Preludes to Urbanism: The Late Chalcolithic of Mesopotamia, McDonald Institute for Archaeological Research, Cambridge, pp. 175-188.

McMahon, A. (2015). Waste management in early urban southern Mesopotamia. In Mitchell, P. (ed.), Sanitation, Latrines and Intestinal Parasites in Past Populations, Ashgate, Farnham, UK, pp. 19-39.

McMahon, A. (2016). The encultured vulture: Late Chalcolithic sealing images and the challenges of urbanism in 4th millennium BC northern Mesopotamia. Paléorient 42(1): 169-183. 
McMahon, A. (2017). How many Sumerians does it take to put out the rubbish? In Heffron, Y., Stone, A., and Worthington, M. (eds.), At the Dawn of History, Ancient Near Eastern Studies in Honour of J. N. Postgate, Eisenbrauns, Winona Lake, IN, pp. 373-392.

McMahon, A., and Oates, J. (2007). Excavations at Tell Brak, 2006 and 2007. Iraq 69: 145-171.

McMahon, A., Soltysiak A., and Weber, J. (2011). Late Chalcolithic mass graves at Tell Brak, Syria, and violent conflict during the growth of early city-states. Journal of Field Archaeology 36: 201-220.

McMahon, A., and Stone, A. (2013). The edge of the city: Urban growth and burial space in 4th millennium BC Mesopotamia. Origini 35: 83-109.

Meijer, D. (1986). A Survey in Northeastern Syria, Netherlands Historical-Archaeological Institute, Istanbul.

Menze, B., and Ur, J. (2012). Mapping patterns of long-term settlement in northern Mesopotamia at a large scale. Proceedings of the National Academy of Sciences USA 109: 5146-5147.

Meyer, J.-W. (2010). Überlegungen zur Siedlungsstruktur: Eine erste Analyse des Ergebnisse des geomagnetischen Prospektion. In Meyer, J.-W., and Orthmann, W. (eds.), Ausgrabungen in Tell Chuera in Nordost-Syrien: Vorbericht zu den Grabungskampagnen 1998 bis 2005, Vorderasiatische Forschungen der Max-Freiherr-von-Oppenheim-Stiftung, Saarbrücken, pp. 199-222.

Modelski, G. (2003). World Cities, -3000 to 2000, Faros 2000, Washington, DC.

Morris, I. (2006). The growth of Greek cities in the first millennium BC. In Storey, G. (ed.), Urbanism in the Preindustrial World: Cross-Cultural Approaches, University of Alabama Press, Tuscaloosa, pp. 27-51.

Neuwirth, R. (2011). Stealth of Nations: The Global Rise of the Informal Economy, Pantheon, New York.

Nichols, D. (2006). Shining stars and black holes: Population and preindustrial cities. In Storey, G. (ed.), Urbanism in the Preindustrial World: Cross-Cultural Approaches, University of Alabama Press, Tuscaloosa, pp. 330-340.

Nissen, H. (1988). The Early History of the Ancient Near East, 9000-2000 BC, University of Chicago Press, Chicago.

Nissen, H. (2001). Cultural and political networks in the ancient Near East during the fourth and third millennia BC. In Rothman, M. (ed.), Uruk Mesopotamia and Its Neighbors: Cross-Cultural Interactions in the Era of State Formation, School of American Research Press, Santa Fe, NM, pp. 149-180.

Nissen, H. (2002). Uruk: Key site of the period and key site of the problem. In Postgate, J. N. (ed.), Artefacts of Complexity; Tracking the Uruk in the Near East, British School of Archaeology in Iraq, London, pp. 1-16.

Oates, D. (1985). Excavations at Tell Brak, 1983-84. Iraq 47: 159-174.

Oates, D. (1987). Excavations at Tell Brak 1985-86. Iraq 49: 175-192.

Oates, D., and Oates, J. (1991). Excavations at Tell Brak 1990-91. Iraq 53: 127-146.

Oates, D., and Oates, J. (1993). Excavations at Tell Brak 1992-93. Iraq 55: 155-200.

Oates, D., and Oates, J. (1997). An open gate: Cities of the fourth millennium BC (Tell Brak 1997). Cambridge Archaeological Journal 7: 287-297.

Oates, D., and Oates, J. 2002. The reattribution of Middle Uruk materials at Brak. In Ehrenberg, E. (ed.), Leaving No Stone Unturned: Essays on the Ancient Near East and Egypt in Honor of Donald P. Hansen, Eisenbrauns, Winona Lake, IN, pp. 145-154.

Oates, J. (1985). Tell Brak: Uruk pottery from the 1984 Season. Iraq 47: 175-186.

Oates, J. (1986). The Uruk/Early Dynastic sequence. In Finkbeiner, U., and Röllig, W. (eds.), Gamdat Nasr, Period or Regional Style? Ludwig Reichert, Weisbaden, pp. 245-271.

Oates, J. (2005). Digging deeper at Tell Brak. Proceedings of the British Academy 131: 1-39.

Oates, J. (2012). The Terminal Ubaid (LC 1) level at Tell Brak. In Marro, C. (ed.), After the Ubaid: Interpreting Change from the Caucasus to Mesopotamia at the Dawn of Urban Civilization (4500-3500 BC), De Boccard, Paris, pp. 66-86.

Oates, J., McMahon, A., Karsgaard, P., al-Quntar, S., and Ur, J. (2007). Early Mesopotamian urbanism: A new view from the north. Antiquity 81: 585-600.

Osborne, J. (2015). Ancient cities and power: The archaeology of urbanism in the Iron Age capitals of northern Mesopotamia. International Journal of Urban Sciences 19: 7-19.

Otto, A. (2006). Alltag und Gesellschaft zur Spätbronzezeit: Eine Fallstudie aus Tall Bazi (Syrien), Subartu 19, Brepols, Turnhout. 
Paine, R., and Storey, G. (2006). Epidemics, age at death, and mortality in ancient Rome. In Storey, G. (ed.), Urbanism in the Preindustrial World: Cross-Cultural Approaches, University of Alabama Press, Tuscaloosa, pp. 69-85.

Parker, B., Dodd, L., Creekmore, A., Healey, E., and Painter, C. (2006). The Upper Tigris Archaeological Research Project (UTARP)_A preliminary report from the 2003 and 2004 field seasons at Kenan Tepe. Anatolica 32: 71-151.

Parker, B., Foster, C., Henecke, J., Hopwood, M., Hopwood, D., Creekmore, A., Demierergi, A., and Eppihimer, M. (2008). Preliminary report from the 2005-2006 field seasons at Kenan Tepe. Anatolica 34: 103-176.

Pearce, J. (2000). The Late Chalcolithic sequence at Hacinebi Tepe, Turkey. In Marro, C., and Hauptman, H. (eds.), Chronologies des pays du Caucase et de l'Euphrate aux IVe-IIIe millenaires, Institut Français d'Études Anatoliennes, Istanbul, pp. 115-143.

Peyronel, L., and Vacca, A. (2016). Northern Ubaid and Late Chalcolithic 1-3 periods in the Erbil Plain: New insights from recent researches at Helawa, Iraqi Kurdistan. Origini 37: 89-127.

Peyronel, L., Vacca, A., and Zenoni, G. (2016). Helawa: A new Northern Ubaid/Late Chalcolithic site in the Erbil Plain. In Kopanias, K., and MacGinnis, J. (eds.), The Archaeology of the Kurdistan Region of Iraq and Adjacent Regions, Archaeopress, Oxford, pp. 309-321.

Pittman, H. (1999). Administrative evidence from Hacinebi Tepe: An essay on the local and the colonial. Paléorient 25(1): 43-50.

Pittman, H. (2001). Mesopotamian intraregional relations reflected through glyptic evidence in the Late Chalcolithic 1-5 periods. In Rothman, M. (ed.), Uruk Mesopotamia and Its Neighbors: Cross-Cultural Interactions in the Era of State Formation, School of American Research Press, Santa Fe, NM, pp. 403-443.

Poidebard, A. (1927). Les routes anciennes en haute-Djezireh. Syria 8: 55-65.

Pollock, S. (1990). Archaeological investigations on the Uruk mound, Abu Salabikh, Iraq. Iraq 52: 85-93.

Pollock, S., Steele, C., and Pope, M. (1991). Investigations on the Uruk mound, Abu Salabikh, 1990. Iraq 53: 59-68.

Postgate, J. N. (1994). How many Sumerians per hectare? Probing the anatomy of an early city. Cambridge Archaeological Journal 4: 47-65.

Pournelle, J. (2003). Marshland of Cities: Deltaic Landscapes and the Evolution of Early Mesopotamian Civilization, Ph.D. dissertation, Department of Anthropology, University of California, San Diego.

Pournelle J. (2007). KLM to CORONA: A bird's-eye view of cultural ecology and early Mesopotamian urbanization. In Stone, E., (ed.), Settlement and Society: Essays Dedicated to Robert McCormick Adams, Cotsen Institute of Archaeology, University of California, Los Angeles, pp. 29-62.

Reade, J. (1973). Tell Taya (1972-73): Summary report. Iraq 35: 155-187.

Redman, C., and Kinzig, A. (2003). Resilience of past landscapes: Resilience theory, society, and the longue durée. Conservation Ecology 7: Art. 14.

Reichel, C. (2002). Administrative complexity in Syria during the fourth millennium B.C.-The seals and sealings from Tell Hamoukar. Akkadica 123: 35-56.

Reichel, C. (2009). Beyond the Garden of Eden-Competition and early warfare in northern Syria (45003000 BC). In Meller, H. (ed.), Schlachfeldarchäologie—Battlefield Archaeology, Landesdenkmalamt, Halle, pp. 17-30.

Rich, J., and Wallace-Hadrill, A. (1991). City and Country in the Ancient World, Taylor and Francis, London.

Riehl, S., Pustovoytov, K., Weippert, H., Klett, S., and Hole, F. (2014). Drought stress variability in ancient Near Eastern agricultural systems evidenced by $\partial^{13} \mathrm{C}$ in barley grain. Proceedings of the National Academy of Sciences USA 111: 12348-12353.

Ristvet, L. (2005). Settlement, Economy and Society in the Tell Leilan Region, Syria, 3000-1000 BC, Ph.D. dissertation, Faculty of Oriental Studies, University of Cambridge, Cambridge.

Roberts, N., Eastwood, W., Kuzucuoğlu, C., Fiorentino, G., and Caracuta, V. (2011). Climatic, vegetation and cultural change in the eastern Mediterranean during the mid-Holocene environmental transition. The Holocene 21: 147-162.

Rothman, M. (2001). The local and the regional: An introduction. In Rothman, M. (ed.), Uruk Mesopotamia and Its Neighbors: Cross-Cultural Interactions in the Era of State Formation, School of American Research Press, Santa Fe, NM, pp. 3-26.

Rothman, M. (2002). Tepe Gawra: The Evolution of a Small, Prehistoric Center in Northern Iraq, University of Pennsylvania Museum of Archaeology and Anthropology, Philadelphia. 
Rothman, M. (2004). Studying the development of complex society: Mesopotamia in the late fifth and fourth millennia BC. Journal of Archaeological Research 12: 75-119.

Rothman, M. (2009). Religion, function, and social networks: Tepe Gawra in the late fifth and early fourth millennia BC. In Butterlin, P. (ed.), À propos de Tepe Gawra: Le monde proto-urbain de Mésopotamie, Subartu 23, Brepols, Turnhout, pp. 15-39.

Rothman, M., and Peasnall, B. (1999). Societal evolution of small, pre-state centers and polities: The example of Tepe Gawra in northern Mesopotamia. Paléorient 25(1): 101-114.

Rova, E. (1999-2000). A tentative synchronisation of the local Late Chalcolithic ceramic horizons of northern Syro-Mesopotamia. Mesopotamia 34/35: 175-199.

Rupley, E., and Wright, H. (2001). Calibrated radiocarbon age determinations of Uruk-related assemblages. In Rothman, M. (ed.), Uruk Mesopotamia and Its Neighbors: Cross-Cultural Interactions in the Era of State Formation, School of American Research Press, Santa Fe, NM, pp. 85-122.

Safar, F., Mustafa, M.A., and Lloyd, S. 1981. Eridu, State Organization of Antiquities and Heritage, Baghdad.

Schwartz, G. (1988a). Excavations at Karatut Mevkii and perspectives on the Uruk/Jemdet Nasr expansion. Akkadica 56: 1-41.

Schwartz, G. (1988b). A Ceramic Chronology from Tell Leilan Operation 1, Yale University Press, New Haven, CT.

Schwartz, G. (ed) (2015). Rural Archaeology in Early Urban Northern Mesopotamia: Excavations at Tell al-Raqa'i, Cotsen Institute of Archaeology Press, University of California, Los Angeles.

Schwartz, G., and Falconer, S. (1994). Rural approaches to social complexity. In Schwartz, G., and Falconer, S. (eds.), Archaeological Views from the Countryside: Village Communities in Early Complex Societies, Smithsonian Institution Press, Washington, DC, pp. 1-9.

Skuldbøl, T. (2009). Earliest Urbanism in Northern Mesopotamia, Settlement Development and Suburban Transformation at Tell Brak, Northeastern Syria, 4000-3000 BC, Ph.D. dissertation, Department of Cross-Cultural and Regional Studies, University of Copenhagen, Copenhagen.

Skuldbøl, T., and Colantoni, C. (2016). Tracking early urbanism in the hilly flanks of MesopotamiaThree years of Danish archaeological investigations on the Rania Plain. In Kopanias, K., and MacGinnis, J. (eds.), The Archaeology of the Kurdistan Region of Iraq and Adjacent Regions, Archaeopress, Oxford, pp. 411-415.

Smith, M. E. (2003). Can we read cosmology in ancient Maya city plans? Comment on Ashmore and Sabloff. Latin American Antiquity 14: 221-228.

Smith, M. E. (2007). Form and meaning in the earliest cities: A new approach to ancient urban planning. Journal of Planning History 6: 3-47.

Smith, M. E. (2008). Aztec City-State Capitals, University Press of Florida, Gainesville.

Smith, M. E. (2010). Sprawl, squatters and sustainable cities: Can archaeological data shed light on modern urban issues? Cambridge Archaeological Journal 20: 229-253.

Smith, M. E. (2016). How can archaeologists identify early cities? Definitions, types, and attributes. In Fernández-Götz, M., and Krausse, D. (eds.), Eurasia at the Dawn of History: Urbanization and Social Change, Cambridge University Press, Cambridge, pp. 153-168.

Smith, M. L. (2003). Introduction: The social construction of ancient cities. In Smith, M. L. (ed.), The Social Construction of Ancient Cities, Smithsonian Books, Washington, DC, pp. 1-36.

Smith, M. L. (2014). The Archaeology of Urban Landscapes. Annual Review of Anthropology 43: $307-323$.

Speiser, E. (1935). Excavations at Tepe Gawra, Vol. 1, University of Pennsylvania Press, Philadelphia.

Stein, G. (1999). Rethinking World-Systems: Diasporas, Colonies, and Interaction in Uruk Mesopotamia, University of Arizona Press, Tucson.

Stein, G. (2001). Indigenous social complexity at Hacinebi (Turkey) and the organization of cultural contact in the Uruk expansion. In Rothman, M. (ed.), Uruk Mesopotamia and Its Neighbors: CrossCultural Interactions in the Era of State Formation, School of American Research Press, Santa Fe, NM, pp. 265-305.

Stein, G. (2002). From passive periphery to active agents: Emerging perspectives in the archaeology of interregional interaction. American Anthropologist, New Series 104: 903-916.

Stein, G. (2009). Tell Zeidan (2008). Oriental Institute Annual Report, 2008-2009: 126-137.

Stein, G. (2010). Tell Zeidan (2009). Oriental Institute Annual Report, 2009-2010: 105-118.

Stein, G. (2011). Tell Zeidan. The Oriental Institute Annual Report, 2010-2011: 122-139.

Stein, G. (2012). The development of indigenous social complexity in Late Chalcolithic Upper Mesopotamia in the fifth-fourth millennia BC: An initial assessment. Origini 34: 125-151. 
Stein, G., Alizadeh, A., Ahmadzadeh, L., Alden, J., Backhaus, H., Coutouraud, B., et al. (2015). Preliminary report on the first season of excavations at the Chalcolithic site of Surezha in the Erbil Governorate, Kurdistan Region, 2013. Iranian Archaeology 4: 32-41.

Stein, G., Bernbeck, R., Coursey, C, McMahon, A., Miller, N., Misir, A., et al. (1996). Uruk colonial expansion and Mesopotamian communities: An interim report on the 1992-3 excavations at Hacinebi, Turkey. American Journal of Archaeology 100: 205-260.

Stein, G., Boden, K., Edens, C, Pearce Edens, J., Keith, K., McMahon, A., and Ôzbal, H. (1997). Excavations at Hacinebi Turkey-1996 preliminary report. Anatolica 23: 111-171.

Stein, G., Edens, C., Pearce Edens, J., Boden, K., Laneri, N., Ôzbal, H., et al. (1998). Southeast Anatolia before the Uruk expansion: Preliminary report on the 1997 excavations at Hacinebi, Turkey. Anatolica 24: 143-193.

Stein, G., and Wattenmaker, P. (2003). Settlement trends and the emergence of social complexity in the Leilan region of the Habur Plains (Syria) from the fourth to the third millennium BC. In Rova, E., and Weiss, H. (eds.), The Origins of North Mesopotamian Civilization: Ninevite 5 Chronology, Economy, Society, Subartu 9, Brepols, Turnhout, pp. 361-386.

Steinert, U. (2011). Akkadian terms for streets and the topography of Mesopotamian cities. Altorientalische Forschungen 38: 309-347.

Storey, R. (2006). Mortality through time in an impoverished residence of the Precolumbian city of Teotihuacan: A palaeodemographic view. In Storey, G. (ed.), Urbanism in the Preindustrial World: Cross-Cultural Approaches, University of Alabama Press, Tuscaloosa, pp. 277-294.

Strommenger, E. (1980). Habuba Kabira: Eine Stadt vor 5000 Jahren, von Zabern, Mainz.

Stronach, D. (1994). Village to metropolis: Nineveh and the beginnings of urbanism in northern Mesopotamia. In Mazzoni, S. (ed.), Nuove fondazioni nel Vicino Oriente antico: Realta`e ideologia, Giardini, Pisa, pp. 85-114.

Styring, A., Charles, M., Fantone, F., Hald, M. M., McMahon, A., Meadow, R., et al. (2017). Isotope evidence for agricultural extensification reveals how the world's first cities were fed. Nature Plants $\mathbf{3}$ : 17076. https://doi.org/10.1038/nplants.2017.76

Sudjic, D. (2016). The Language of Cities, Allen Lane, London.

Sudo, H. (2010). The development of wool exploitation in Ubaid-period settlements of North Mesopotamia. In Carter, R., and Philip, G. (eds.), Beyond the Ubaid: Transformations and Integration in the Late Prehistoric Societies of the Middle East, Studies in Ancient Oriental Civilization 63, Oriental Institute, Chicago, pp. 169-179.

Tobler, A. (1950). Excavations at Tepe Gawra Vol. 2, University of Pennsylvania Press, Philadelphia.

Tomé, A., Cabral, R., and Renette, S. (2016). The Kani Shaie Archaeological Project. In Kopanias, K., and MacGinnis, J. (eds.), The Archaeology of the Kurdistan Region of Iraq and Adjacent Regions, Archaeopress, Oxford, pp. 427-434.

Trufelli, F. (1997). Ceramic correlations and cultural relations in IVth millennium eastern Anatolia and Syro-Mesopotamia. Studi Micenei ed Egeo-Anatolici 39: 5-33.

Ur, J. (2002a). Settlement and landscape in northern Mesopotamia: The Tell Hamoukar Survey 20002001. Akkadica 123: 57-88.

Ur, J. (2002b). Surface collection and offsite studies at Tell Hamoukar. Iraq 64: 15-44.

Ur, J. (2003). CORONA satellite photography and ancient road networks: A northern Mesopotamian case study. Antiquity 77: 102-115.

Ur, J. (2005). Sennacherib's northern Assyrian canals: New insights from satellite imagery and aerial photography. Iraq 67: 317-345.

Ur, J. (2009). Emergent landscapes of movement in Early Bronze Age northern Mesopotamia. In Snead, J., Erickson, C., and Darling. J. (eds.), Landscapes of Movement: Trails, Paths, and Roads in Anthropological Perspective, University of Pennsylvania Museum of Archaeology and Anthropology, Philadelphia, pp. 180-203.

Ur, J. (2010a). Cycles of civilisation in northern Mesopotamia, 4400-2000 BC. Journal of Archaeological Research 18: 387-431.

Ur, J. (2010b). Urbanism and Cultural Landscapes in Northeastern Syria: The Tell Hamoukar Survey, 1999-2001, Oriental Institute Publications 137, Oriental Institute, Chicago.

Ur, J. (2013). Spying on the past: Declassified intelligence satellite photographs and Near Eastern landscapes. Near Eastern Archaeology 76: 28-36.

Ur, J. (2014). Urban form at Tell Brak across three millennia. In McMahon, A., and Crawford, H. (eds.), Preludes to Urbanism: The Late Chalcolithic of Mesopotamia, McDonald Institute for Archaeological Research, Cambridge, pp. 49-62. 
Ur, J. (2015). Urban adaptations to climate change in northern Mesopotamia. In Kerner, S., Dann, R., and Bangsgaard, P. (eds.), Climate and Ancient Societies, Museum Tusculanum Press, Copenhagen, pp. 69-95.

Ur, J. (2016). Challenges in early urbanism: A view from Mesopotamia. Norwegian Archaeological Review 49: 70-72.

Ur, J., Karsgaard, P., and Oates, J. (2007). Early urban development in the ancient Near East. Science 317: 1188 .

Ur, J., Karsgaard, P., and Oates, J. (2011). The spatial dimensions of early Mesopotamian urbanism: The Tell Brak Suburban Survey 2003-2006. Iraq 73: 1-19.

Ur, J., de Jong, L., Giraud, J., Osborne, J., and MacGinnis, J. (2013). Ancient cities and landscapes in the Kurdistan region of Iraq: The Erbil Plain Archaeological Survey 2012 Season. Iraq 75: 89-117.

Ur, J., and Osborne, J. (2016). The rural landscape of the Assyrian heartland: Recent results from Arbail and Kilizu provinces. In MacGinnis, J., Wicke, D., and Greenfield, T. (eds.), The Provincial Archaeology of the Assyrian Empire, McDonald Institute for Archaeological Research, Cambridge, pp. 163-174.

Ur, J., and Wilkinson, T. (2008). Settlement and economic landscapes of Tell Beydar and its hinterland. In Lebeau, M., and Suleiman, A. (eds.), Beydar Studies I, Subartu 21, Brepols, Turnhout, pp. 305-327.

Vallet, R. (1997). Habuba Kebira ou la naissance de l'urbanisme. Paléorient 22(2): 45-76.

Van de Mieroop, M. (1997). The Ancient Mesopotamian City, Oxford University Press, Oxford.

Van Liere, W., and Lauffray, J. (1954/55). Nouvelle prospection archéologique dans la Haute Djéziréh syrienne. Annales Archéologique Syrienne 4-5: 129-148.

Vignola, C., Balossi Restelli, F., Masi, A, Sadori, L., and Siracuso, G. (2014). Investigating domestic economy at the beginning of the Late Chalcolithic in eastern Anatolia: The case of Arslantepe period VIII. Origini 36: 7-36.

Wallace, M., Jones, G., Charles, M., Fraser, R., Heaton, T., and Bogaard, A. (2015). Stable carbon isotope evidence for Neolithic and Bronze Age crop water management in the eastern Mediterranean and Southwest Asia. PLoS One 10(6): e0127085 https://doi.org/10.1371/journal.pone.0127085 Accessed June 2018.

Weber, J. (2014). Exotic animal consumption at Tell Brak in the mid-fourth millennium BC. In McMahon, A., and Crawford, H. (eds.), Preludes to Urbanism: The Late Chalcolithic of Mesopotamia, McDonald Institute for Archaeological Research, Cambridge, pp. 127-134.

Wengrow, D., Carter, R., Brereton, G., Shepperson, M., Hamarashi, S. J., Saber, S. A., et al. (2016). Gurga Chiya and Tepe Marani: New excavations in the Shahrizor Plain, Iraqi Kurdistan. Iraq 78: 253-284.

Wilkinson, T. (1993). Linear hollows in the Jazira, Upper Mesopotamia. Antiquity 67: 548-562.

Wilkinson, T. (1994). The structure and dynamics of dry-farming states in Upper Mesopotamia. Current Anthropology 35: 483-520.

Wilkinson, T. (1997). Environmental fluctuations, agricultural production and collapse: A view from Bronze Age Upper Mesopotamia. In Dalfes, H., Kukla, G., and Weiss, H. (eds.), Third Millennium BC Climate Change and Old World Collapse, Springer, Berlin, pp. 67-106.

Wilkinson, T. (2000). Regional approaches to Mesopotamian archaeology: The contribution of archaeological surveys. Journal of Archaeological Research 8: 219-267.

Wilkinson, T. (2002). Physical and cultural landscapes of the Hamoukar area. Akkadica 123: 89-105.

Wilkinson, T. (2003). Archaeological Landscapes of the Near East, University of Arizona Press, Tucson.

Wilkinson, T., and Tucker, D. (1995). Settlement Development in the North Jazira, Iraq: A Study of the Archaeological Landscape, Aris and Phillips, Warminster.

Wilkinson, T., French, C., Matthews, W., and Oates, J. (2001). Tell Brak: Geoarchaeology, landscape and the region. In Oates, D., Oates, J., and McDonald, H. (eds.), Excavations at Tell Brak 2: Nagar in the Third Millennium BC, McDonald Institute for Archaeological Research, Cambridge, pp. 1-14.

Wilkinson, T., and Rayne, L. (2010). Hydraulic landscapes and imperial power. Water History 2: $115-144$.

Wilkinson, T., Galiatsatos, N., Lawrence, D., Ricci, A., Philip G., and Dunford, R. (2012). Late Chalcolithic and Early Bronze Age landscapes of settlement and mobility in the Middle Euphrates: A reassessment. Levant 44: 139-85.

Wilkinson, T., Gibson, M., and Widell, M. (eds.) (2013). Models of Mesopotamian Landscapes: How Small-Scale Processes Contributed to the Growth of Early Civilizations, BAR International Series 2552, Archaeopress, Oxford. 
Wilkinson, T., Philip, G., Bradbury, J., Dunford, R., Donoghue, D., Galiatsatos, N., et al. (2014a). Contextualizing early urbanization: Settlement cores, early states and agro-pastoral strategies in the Fertile Crescent during the fourth and third millennia BC. Journal of World Prehistory 27: 43-109.

Wilkinson, T., French, C., and Semple, M. (2014b). Hollow ways and routes around Tell Brak. In McMahon, A., and Crawford, H. (eds.), Preludes to Urbanism; The Late Chalcolithic of Mesopotamia, McDonald Institute for Archaeological Research, Cambridge, pp. 35-47.

Woolley, L., and Mallowan, M. (1976). Ur Excavations Vol. VII: The Old Babylonian Period, British Museum, London.

Wright, H. (1981). The southern margins of Sumer: Archaeological survey of the area of Eridu and Ur. In Adams, R. McC., Heartland of Cities, University of Chicago Press, Chicago, pp. 295-345.

Wright, H., Rupley, E., Ur, J., Oates, J., and Ganem, E. (2007). Preliminary report on the 2002 and 2003 seasons of the Tell Brak Sustaining Area Survey. Annales Archéologiques Arabes Syriennes 49/50: 7-21.

Yoffee, N. (1995). Political economy in early Mesopotamian states. Annual Review of Anthropology 24: $281-311$.

Yoffee, N. (2015). Conclusion: The meanings of early cities. In Yoffee, N. (ed.), The Cambridge World History Vol. III: Early Cities in Comparative Perspective, 4000 BCE-1200CE, Cambridge University Press, Cambridge, pp. 546-557.

Zeder, M. (2003). Food provisioning in urban societies; A view from northern Mesopotamia. In Smith, M. L. (ed.), The Social Construction of Ancient Cities, Smithsonian Books, Washington, DC, pp. $156-183$.

\section{Bibliography of Recent Literature}

Algaze, G. (2013). The end of prehistory and the Uruk Period. In Crawford, H. (ed.), The Sumerian World, Routledge, London, pp. 68-94.

Algaze, G. (2017). Demographic trends in early Mesopotamian urbanism. In Maner, Ç., Horowitz, M., and Gilbert, A. (eds.), Overturning Certainties in Near Eastern Archaeology, Brill, Leiden, pp. 25-33.

Algaze, G. (2018). The tyranny of friction. Origini 42: 73-92.

Altaweel, M. (2008). Investigating agricultural sustainability and strategies in northern Mesopotamia: Results produced using a socio-ecological modeling approach. Journal of Archaeological Science 35: 821-836.

Ball, W. (ed.) (2003). Ancient Settlement in the Zammar Region, Excavations by the British Archaeological Expedition to Iraq in the Saddam Dam Salvage Project 1985-1986, BAR International Series 1096, Archaeopress, Oxford.

Balossi Restelli, F. (2012). Eating at home and 'dining' out? Commensalities in the Neolithic and Late Chalcolithic in the Near East. In Pollock, S. (ed.), Between Feasts and Daily Meals: Toward an Archaeology of Commensal Spaces. E-TOPOI vol. 2: 75-95.

Brustolon, A., and Rova, E. (2008). The Late Chalcolithic settlement in the Leilan region of northeast Syria. In Cordoba, J., Molist, M., Perez, M., Rubio, I., and Martinez, S. (eds.), Proceedings of the 5th International Congress on the Archaeology of the Ancient Near East, Universidad Autónoma of Madrid, Madrid, pp. 357-382.

Butterlin, P. (2018). Sixty years after City Invincible, surveys and the urban revolution in question. Origini 42: 45-60.

Chase, A., and Chase, D. (2016). Urbanism and anthropogenic landscapes. Annual Review of Anthropology 45: 361-376.

D'Anna, M., and Guarino, P. (2012). Pottery production and use at Arslantepe between periods VII and VIA, evidence for social and economic change. Origini 34: 59-77.

Deckers, K., and Riehl, S. (2008). Resource exploitation of the Upper Khabur Basin (NE Syria) during the third millennium BC. Paléorient 34(2): 173-189.

deGruchy, M., Deckers, K., and Riehl, S. (2016). A diachronic reconstruction of the northern Mesopotamian landscape (4th to 2nd millennia BC) from three separate sources of evidence. Journal of Archaeological Science Reports 8: 250-267.

Delle Donne, M. (2019). Agriculture and food habit of the Syrian Jazira in the Late Chalcolithic 3: New archaeobotanical data from Tell Mozan. Annali, Sezione Orientale 79: 111-125. 
Emberling, G. (2015). Mesopotamian cities and urban process, 3500-1600 BCE. In Yoffee, N. (ed.), Early Cities in Comparative Perspective, Cambridge University Press, Cambridge, pp. 253-278.

Emberling, G., and Minc, L. (2016). Ceramics and long-distance trade in early Mesopotamian states. Journal of Archaeological Science Reports 7: 819-834.

Frangipane, M. (2010). Different models of power structuring at the rise of hierarchical societies in the Near East: Primary economy versus luxury and defence management. In Bolger, D., and Maguire, L. (eds.), The Development of Pre-State Communities in the Ancient Near East: Studies in Honour of Edgar Peltenburg, Oxbow Books, Oxford, pp. 79-86.

Gibson, M. (2000). Tell Hamoukar, early city in northeastern Syria. Antiquity 74: 477-478.

Jennings, J., and Earle, T. (2016). Urbanization, state formation and cooperation, A reappraisal. Current Anthropology 57: 474-493.

Lawrence, D., Philip, G., Hunt, H., Snape-Kennedy, L., and Wilkinson, T. J. (2016). Long term population, city size and climate trends in the Fertile Crescent: A first approximation. PLoS ONE 11(3) doi.org/https://doi.org/10.1371/journal.pone.0152563

Marro, C. (ed.) (2012). After the Ubaid: Interpreting Change from the Caucasus to Mesopotamia at the Dawn of Urban Civilization (4500-3500 BC), Institut français d'études anatoliennes, Istanbul.

McMahon, A. (2013). Mesopotamia. In Clark, P. (ed.). The Oxford Handbook of Cities in Global History, Oxford, Oxford University Press, pp. 31-48.

Menze, B., Mühl, S., and Sherratt, A. (2007). Virtual survey on North Mesopotamia tell sites by means of remote sensing. In Ooghe, B., and Verhoeven, G. (eds.), Broadening Horizons. Multidisciplinary Approaches to the Study of Past Landscapes, Cambridge Scholars Press, Cambridge, pp. 1-17.

Minc, L., and Emberling, G. (2016). Trade and interaction during the era of the Uruk expansion: Recent insights from archaeometric analyses. Journal of Archaeological Science Reports 7: 793-797.

Nissen, H. (2018). The city of Uruk and its hinterland. Origini 42: 61-71.

Pittman, H. (2012). Interregional interaction at Arslantepe: The glyptic evidence of Level VII. Origini 34: $79-95$.

Pittman, H. (2013). Imagery in administrative context: Susiana and the west in the fourth millennium BC. In Petrie, C. (ed.), Ancient Iran and Its Neighbors: Local Developments and Long-Range Interactions in the 4th Millennium BC, Oxbow Publications, Oxford, pp. 293-336.

Pittman, H., and Blackman, J. (2016). Mobile or stationary? Chemical analysis of clay administrative devices from Tell Brak in the Late Uruk period. Journal of Archaeological Science Reports 7: 877-883.

Smith, M. E., Ur, J., and Feinman, G. (2014). Jane Jacobs' 'cities first' model and archaeological reality. International Journal of Urban and Regional Research 38: 1525-1535.

Smith, S., Wilkinson, T., and Lawrence, D. (2014). Agro-pastoral landscapes in the zone of uncertainty: The Middle Euphrates and the north Syrian steppe during the 4th and 3rd millennia BC. In Morandi Bonacossi, D. (ed.) Settlement Dynamics and Human-Landscape Interaction in the Dry Steppes of Syria, Harrassowitz, Wiesbaden, pp. 151-72.

Stone, E., (2007). The Mesopotamian urban experience. In Stone, E. (ed,) Settlement and Society: Essays Dedicated to Robert McCormick Adams, Cotsen Institute of Archaeology, University of California, Los Angeles, pp. 213-234.

Ur, J. (2017). The birth of cities in ancient West Asia. In Tsuneki A., Yamada S., and Hisada, K. (eds.), Ancient West Asian Civilization, Springer, Singapore.

Ur, J. (2014). Households and the emergence of cities in ancient Mesopotamia. Cambridge Archaeological Journal 24: 249-268.

Wilkinson, T., French, C. Ur, J., and Semple, M. (2010). The geoarchaeology of route systems in northern Syria. Geoarchaeology 25: 745-71.

Wright, H. (2014). Early Uruk ceramic assemblages: Cultural relations in Greater Mesopotamia during the late fifth and early fourth millennia BC. In McMahon, A., and Crawford, H. (eds.), Preludes to Urbanism: The Late Chalcolithic of Mesopotamia, McDonald Institute for Archaeological Research, Cambridge, pp. 109-125.

Wright, H. (2016). The Uruk expansion and beyond: Archaeometric and social perspectives on exchange in the IVth millennium BCE. Journal of Archaeological Science Reports 7: 900-904.

Publisher's Note Springer Nature remains neutral with regard to jurisdictional claims in published maps and institutional affiliations. 